PRZEGLĄD NAUK HISTORYCZNYCH 2017, R. XVI, NR 1

http://dx.doi.org/10.18778/1644-857X.16.01.01

ARTYKUEY, STUDIA I ROZPRAWY

\author{
Maciej KokoszKo \\ UNIWERSYTET ŁÓDZKI ${ }^{*}$ \\ KRZYSZTOF JAGUSIAK \\ UNIWERSYTET ŁÓDZKI* \\ Jolanta Dybata \\ Uniwersytet Jana Kochanowskiego \\ Filia w Piotrkowie Trybunalskim ${ }^{* * *}$
}

\title{
Nauka o mleku zawarta w twórczości Dioskuridesa. Studium źródłowe
}

Streszczenie. Poniższy tekst dotyczy przede wszystkim zastosowania mleka i uzyskiwanych $z$ niego produktów, tj. serwatki, sera i masła, w medycynie okresu wczesnego Cesarstwa Rzymskiego ukazanej przez pryzmat dwóch greckich dzieł (obu prawdopodobnie) autorstwa Dioskuridesa znanych pod łacińskimi tytułami De materia medica i Euporista vel de simplicibus medicinis. Ważna jego część stanowia jednak również analizy tych fragmentów obu wymienionych traktatów, które maja charakter pozamedyczny i dotyczą kwestii związanych $z$ technologia spożywcza, kwantyfikacja rodzajów mleka czy metodami hodowli zwierząt mlecznych. Obok zatem informacji dotyczących terapeutycznych właściwości opisywanych produktów i szeregu przykładów ich praktycznych zastosowań w lecznictwie uprawianym przez Dioskuridesa, czy szerzej: medyków w początkach naszej ery, omawiamy m.in. znajdujace się u tego autora zalecenia dotyczace technologii gotowania mleka, uwagi dotyczące wpływu paszy na jakość udojonego płynu czy metody produkcji stosowane w ówczesnym serowarstwie. Zaczerpnięte $z$ Dioskuridesowej spuścizny dane (zamieszczone przezeń niejako na marginesie jego głównego wywodu dotyczącego sztuki medycznej) uzupełnione wiadomościami pochodzacymi z traktatów innych autorów tej epoki, jak Celsus, Pliniusz Starszy

*Wydział Filozoficzno-Historyczny, Instytut Historii, Katedra Historii Bizancjum, e-mail: mkokoszko@komandor.pl.

${ }^{* *}$ Centrum Badań nad Historia i Kultura Basenu Morza Śródziemnego i Europy Południowo-Wschodniej im. prof. Waldemara Cerana, Ceraneum, e-mail: jagusiak@biol.uni.lodz.pl.

*** Biblioteka Uniwersytetu Jana Kochanowskiego, Filia w Piotrkowie Trybunalskim, e-mail: j.dybala@vp.pl. 
i Galen, daja także asumpt do snucia opartych na takim materiale źródłowym i podpartych ustaleniami współczesnej nauki rozważań na temat popularności poszczególnych produktów mlecznych w społeczeństwie grecko-rzymskim okresu wczesnego Cesarstwa czy przyczyn stojących za kształtowaniem się śródziemnomorskiej tradycji kulinarnej (jak np. różnice w konsumpcji nabiału między Grekami i Rzymianami a tzw. barbarzyńcami i ich powody).

$\mathrm{Na}$ podstawie przeprowadzonych badań wnioskować można, że wszyscy znani autorzy z I w. n.e. i późniejszych stuleci (w tym Dioskurides), zajmujący się omówiona w artykule tematyka, byli reprezentantami tej samej, już wówczas ukształtowanej, tradycji, której twórców nie znamy. Stąd duża zbieżność poglądów postaci takich jak Celsus czy Galen, a później Orybazjusz i kolejni bizantyńscy lekarze na temat właściwości nabiału i jego możliwych zastosowań terapeutycznych. Uogólniając, zarówno mleko, jak i wytwarzane $z$ niego produkty były w medycynie stosowane zarówno zewnętrznie, jak i wewnętrznie w różnych formach (jako lekarstwa proste i złożone) i przy różnych dolegliwościach, takich jak dyzenteria, dna moczanowa, choroby o charakterze stomatologicznym, oftalmologicznym, otorynolaryngologicznym, urologicznym i innym.

Słowa kluczowe: Dioskurides, mleko, medycyna antyczna, medycyna bizantyńska, antyczna technologia spożywcza.

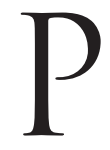
edaniusz Dioskurides $z$ Anazarbos, lekarz związany z armia rzymska I w. n.e. ${ }^{1}$, przeszedł do historii medycyny jako autor dwu napisanych po grecku, lecz funkcjonujących we współczesnej nauce pod łacińskimi tytułami, dzieł. Jego De materia medica jest kolekcja danych na temat różnorodnych substancji

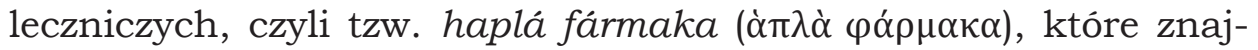
dowały zastosowanie w praktyce terapeutycznej jego czasów. Drugi $z$ przypisywanych mu traktatów, znany jako Euporista vel de simplicibus medicinis, referowal wykorzystanie, wyliczonych i scharakteryzowanych w De materia medica prostych medykamentów w kuracjach konkretnych dolegliwości. Oba pisma Dioskuridesa na stałe zakorzeniły się w wykładach teorii terapeutycznej następnych pokoleń ze względu na swą wyczerpująca to zagadnienie naturę, jasność kompozycji oraz stosunkowo prosty (acz fachowy) język wykładu. Historia medycyny pokazuje, że były one świetnie przyswojone przez teoretyków i praktyków sztuki lekarskiej, kształtując ją na niemal dwa tysiąclecia ${ }^{2}$.

${ }^{1}$ Por. Pedanii Dioscuridis Anazarbei De materia medica libri V, I, Prologos, 4, 3, ed. M. Wellmann, vol. I-III, Berolini 1906-1914 [dalej: Di os kurides, De materia medica]; J. Scarborough, Roman medicine and the legions. A reconsideration, „Medical History” 1968, vol. XII, No. 3, s. 254-261.

${ }^{2}$ Wybrana literatura na temat tego lekarza por. J.M. Riddle, Dioscurides on pharmacy and medicine, Austin 1985, passim; M. Kokos zko, Ryby i ich znaczenie w życiu codziennym ludzi późnego antyku i Bizancjum (IV-VII w.), Łódź 2005, s. 12; 
Wśród wymienionych w twórczości lekarza $z$ Anazarbos substancji znajdujemy rozliczne produkty odzwierzęce, w tym także takie

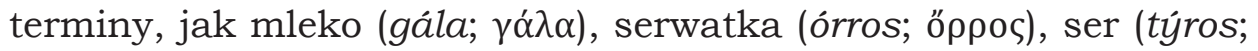

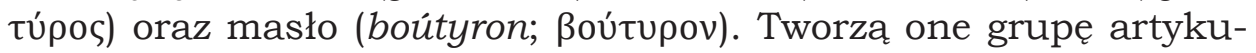
łów, które dziś określamy nabiałem. De materia medica zawiera wiele wzmianek na ich temat. Sa one tak liczne, że szczegółowa analiza wszystkich danych wykraczałaby poza ramy przyjęte w niniejszym studium. Dlatego za materiał do obecnego opusculum przyjęto fragment rzeczonego dzieła stanowiący zbiorczą charakterystykę mleka oraz jego pochodnych, która całościowo oddaje wiedzę Dioskuridesa w interesującym nas zakresie. Znajduje się ona w księdze II De materia medica. Nabiał został tam opisany pod katem właściwości przypisywanych mu przez starożytna medycynę, a autor włączył do swego wykładu liczne informacje na temat sposobów otrzymywania i zastosowania poszczególnych produktów $z$ tej grupy. Pierwsze sa interesujące dla badacza rozwoju medycyny, podczas gdy drugie dostarczaja bezcennych danych $z$ zakresu technologii obróbki pokarmów, a wskutek tego także $z$ dziedziny historii kulinariów. Ponieważ zarówno farmakologia, jak i gastronomia czerpała $z$ zasobów produktów wytwarzanych w basenie Morza Śródziemnego, dorobek Dioskuridesa jest również pełen wskazówek obrazujących stan gospodarki antycznej, a niekiedy także dziejów społeczeństwa zamieszkującego obszar śródziemnomorski. W niniejszym studium analizie poddany został też zasób wiedzy dostępny w traktacie Euporista vel de simplicibus medicinis, który uzupełnia dane zachowane w pierwszym $z$ wymienionych dzieł. Uzyskane informacje spróbujemy nie tylko zrelacjonować (a w ten sposób ukazać główne założenia medycznej teorii mleka i produktów mlecznych), lecz także zanalizować pod kątem historii medycyny, dziejów sztuki kulinarnej oraz stanu gospodarki antycznej znanej autorowi zachowanego traktatu.

\section{Mleko}

Rozważania pragniemy rozpocząć od uwagi oczywistej dla medyków antyku, ale nie zawsze pozostającej w sferze pojęciowej nowożytnych czytelników dzieł Dioskuridesa. Mianowicie już sam fakt włączenia

M. Stamatu, Dioskurides, [w:] Antike medizin. Ein Lexikon, hrsg. K.-H. Leven, München 2005, kol. 227-229; V. Nutton, Ancient medicine, London-New York 2005, s. 174-177; R.A. Gabriel, Man and wound in the ancient world. A history of military medicine from Sumer to the fall of Constantinople, Washington 2012, s. 174-175. 
danych na temat mleka i jego pochodnych do obu traktatów lekarza $z$ Anazarbos niesie ze sobą informację o uznawaniu przez tego autora rzeczonych produktów nie tylko za pokarmy, co wydaje się oczywiste nawet $z$ perspektywy dzisiejszej wiedzy ogólnej, lecz także za substancje o działaniu leczniczym, tzn. fármaka $(\varphi \alpha ́ \rho \mu \alpha \kappa \alpha)^{3}$. Oba dzieła uwypuklaja zreszta funkcję terapeutyczna mleka i produktów mlecznych, pozostawiając na marginesie ich rolę pokarmową. Ta ostatnia jest jednak zaznaczona, a narracja wskazuje, że starożytny autor żył w świecie, w którym nabiał był stosunkowo dostępny. Ta konkluzja znajduje wsparcie w tym, że przedmiot naszych zainteresowań zaliczony został do kategorii substancji określanych

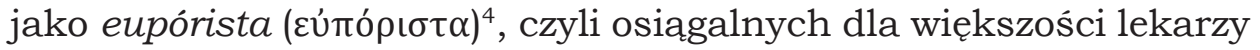
żyjących i praktykujących w czasach Dioskuridesa.

Przechodząc do meritum rozważań, pragniemy zwrócić uwagę, że lekarz z Anazarbos zaczął swój wykład od opisu mleka jako pokarmu, ewaluujacc je jako pożywienie o dobrych sokach. Mleko odznacza się też według niego znaczną odżywczościa i doprowadza do zmiękczenia przewodu pokarmowego ${ }^{5}$, ale jego spożycie przyczynia się również do produkcji gazów zarówno w żołądku, jak i we wnętrznościach. Przytoczone uwagi, choć krótkie, wspierają wyrażone powyżej zdanie, że mleko było powszechnie znanym produktem

${ }^{3}$ Zagadnienie roli produktów spożywczych w farmakologii antycznej i bizantyńskiej por. np. M. Kokos zko, K. Jagusiak, Z. Rzeźnicka, Dietetyka i sztuka kulinarna antyku i wczesnego Bizancjum (II-VII w.), cz. 1 (Zboża i produkty zbożowe w źródłach medycznych antyku $i$ wczesnego Bizancjum), Łódź 2014, passim; e orundem, Cereals of antiquity and early Byzantine times. Wheat and barley in medical sources (second to seventh centuries AD), Łódź 2014, passim; Dietetyka $i$ sztuka kulinarna antyku i wczesnego Bizancjum (II-VII w.), cz. 2 (Pokarm dla ciała i ducha), red. M. Kokoszko, Łódź 2014, passim; M. Kokoszko, K. Jagusiak, Z. Rzeźnicka, Rice as food and medication in ancient and Byzantine medical literature, „Byzantinische Zeitschrift” 2015, Bd. CVIII, Nr. 1, s. 129-155; M. Ko koszko, The Common Oat as Food and Medicament in Greek Medical Treatises of Antiquity and Byzantium, II-VII c. AD, [w:] Tasting Cultures:Thoughts for Food, ed. M.J. Pires, Oxford 2015, s. 99-113; M. Kokos zko, Rzodkiew (Raphanus L.) $w$ wybranych źródłach antyku i Bizancjum, [w:] Lek rośliny 4. Produkty pochodzenia roślinnego $w$ lecznictwie, dietetyce, kosmetyce, ekonomice $i$ kulturze popularnej, red. B. Płonka-Syroka, A. Syroka, Wrocław 2015, s. 15-33; Z. Rzeźnicka, M. Kokoszko, Czosnek $w$ medycynie wczesnego Bizancjum na przykładzie pism Orybazjusza, [w:] Lek rośliny 4..., s. 49-61 etc.

${ }^{4}$ Wzmiankowany zatem został wielokrotnie w dziele Euporista vel de simplicibus medicinis.

${ }^{5}$ Autorowi chodziło o zlikwidowanie wrażenia wypełnienia wnętrzności przez wywołanie wypróżnienia. Mleko zatem było traktowane przez niego jako środek przeczyszczający, gdyż takie działanie miała wchodząca w jego skład serwatka. 
spożywczym, któremu przypisywano działanie terapeutyczne. Skala jego spożycia nie została natomiast sprecyzowana expressis verbis. $Z$ teksu wynika jednak także, że oceniano je jako produkt mogacy powodować problemy zdrowotne, co zapewne wpływało na ograniczenie jego spożycia w celu utrzymania właściwego stanu zdrowia.

W świecie, w którym społeczeństwo żyło w stałym kontakcie ze wsią i stąd znało realia życia $\left(\right.$ oraz pracy $^{6}$ ) poza obszarami zurbanizowanymi, nie dziwi też uwaga Dioskuridesa, że mleko uzyskane wiosną ma większą zawartość wody niż to, które było do dyspozycji latem. Słowa te nawiązuja do ogólnie znanych prawidłowości klimatycznych obszaru śródziemnomorskiego, gdzie wiosna dostarczała wystarczającej ilości opadów, by zapewnić dogodne warunki odradzającej się roślinności, mogącej następnie stanowić bardziej soczysta paszę dla zwierząt mlecznych. Nadto Dioskurides pisał, że mleko udojone od stworzeń, które żywiły się zieloną trawą, ma większe zdolności do wywoływania przeczyszczeń. Podsumowując partię wstępna swego tekstu, lekarz stwierdził również, że cechy fizyczne wyróżniające dobre mleko to jego biały kolor i równomierna gęstość, której miernikiem jest tempo, w jakim spływa kropla płynu, umieszczona na paznokciu palca ${ }^{7}$.

Choć na pierwszy rzut bardzo ogólny i oczywisty, cały ten fragment skłania do konkluzji, że mleko dostępne na rynku w I w. było bardzo zróżnicowane względem swych cech fizycznych. Ta niejednolitość wynikała zapewne $z$ rozpowszechnionej, ale też rozproszonej hodowli niewielkich stad zwierząt mlecznych w bardzo różnorodnych warunkach przyrodniczych, a dalej: $z$ odmienności paszy spożywanej przez zwierzęta. Nadto jego charakterystyka podlegała daleko idącym zmianom w zależności od pór roku, zatem cechowała się sezonowością. Spożywca zatem musiał dokładnie zapoznać się $z$ produktem i umiejętnie ocenić jego przydatność do celów, do których miało ono być wykorzystane. $Z$ racji tego, że mleko było

${ }^{6}$ Bliskie kontakty lekarzy z zapleczem wiejskim sa szczególnie często uwypuklone w twórczości Galena. Ten bowiem wielokrotnie, zwłaszcza w czasach swej młodości, opuszczał rodzinne miasto, by zdobywać doświadczenie praktyczne, w tym także w zakresie sztuki medycznej, na niezurbanizowanych terenach sąsiadujących $z$ Pergamonem. Ta jego działalność została ostatnio wzmiankowana przez nas w: Z. Rzeźnicka, M. Kokoszko, Odchody zwierzęce $w$ terapeutyce późnego antyku $i$ wczesnego Bizancjum na przykładzie pism Galena i Aecjusza $z$ Amidy, [w:] Leki i choroby odzwierzece, t. I, red. L. Wdowiak, B. Płonka-Syroka, A. Syroka, Wrocław 2016, s. 33-46, zwłaszcza 39-42, 44-45.

7 Dioskurides, De materia medica, II, 70, 1, 1-5. 
towarem dostarczanym głównie przez wieś, a w większych ilościach produkowane było tylko tam, gdzie występowała wystarczająca liczba pastwisk, można się też domyślać jego ograniczonej dostępności w miejscach, gdzie nie było wystarczająco paszy, zwłaszcza w dużych miastach, do których trzeba było je dostarczyć skądinąd ${ }^{8}$. Nasuwa się zatem konkluzja o większym spożyciu świeżego mleka poza dużymi centrami miejskimi, ponieważ był to artykuł o krótkiej trwałości, a nie znano efektywnych sposobów przedłużania trwałości tego produktu.

Dioskurides wskazał wyraźnie na najpopularniejsze gatunki mle$\mathrm{ka}$, a narracja mówi wiele o priorytetach hodowlanych ówczesnej gospodarki. Zaczynał zatem od kóz, sugerując w ten sposób szczególną rolę tych zwierząt w hodowli. Twierdził, że ich mleko powoduje mniejsze zaburzenia trawienne, a jako wytłumaczenie tego zjawiska podał fakt, że kozy żywią się pokarmem o właściwościach ściagających ${ }^{9}$, liśćmi i gałąkami lentyszka (Pistacia lentiscus L.), dębu, oliwki i pistacji terpentynowej (Pistacia terebinthus L.) ${ }^{10}$. Stwierdzenia te sa ciekawe wobec cytowanego powyżej świadectwa, że mleko było klasyfikowane jako pokarm powszechnie wywołujacy negatywne skutki dla organizmu. Ponieważ Dioskurides wyraźnie stwierdził, że mleko kozie przyczyniało się do tej dolegliwości w najmniejszym stopniu, niniejsza wypowiedź powinna być traktowana jako przesłanka wskazująca na rozpowszechnioną wśród pacjentów autora De materia medica nietolerancję na laktozę. Kozie mleko jest bowiem najmniej uczulające i dozwolone w dietach dla osób z niedoborem enzymu trawiennego zwanego laktazą ${ }^{11}$.

${ }^{8} \mathrm{Na}$ temat rynków zbytu produktów pochodzenia zwierzęcego w miastach greckich i rzymskich por. T. Howe, Value economics. Animals, wealth, and the market, [w:] The Oxford handbook of animals in classical thought and life, ed. G.L. Campbell, Oxford 2014 [dalej: The Oxford handbook of animals], s. 144-150. Wprawdzie, zwłaszcza w okresie rzymskim, w miastach istniały targi zwierzat, na których można było kupić żywe sztuki należące do różnych gatunków, a także mięso, nie słychać jednak o mleku, chociaż zwierzęta mleczne, nadające się do niewielkiej przydomowej hodowli, takie jak kozy, były w sprzedaży. Wydaje się jednak, że większość mieszkańców miast, stłoczonych w niewielkich przestrzeniach, nie mogła sobie pozwolić na hodowlę choćby jednej sztuki zwierzęcia mlecznego. Na temat niuansów antycznej hodowli zwierzat por. T. How e, Domestication and breeding of livestock. Horses, mules, asses, cattle, sheep, goats, and swine, [w:] The Oxford handbook of animals, s. 99-108.

9 Taki pokarm zmniejsza działanie przeczyszczające mleka.

10 To znaczy nie ma ono silnych właściwości przeczyszczających.

${ }^{11}$ Mleko kozie jest obecnie oceniane jako lekkostrawne, a moga je pić osoby uczulone na mleko krowie, ponieważ nie zawiera znacznych ilości laktozy ani 
Z kolei mleko owcze Dioskurides określał jako gęste i słodkawe. Odznacza się ono też według niego wysoka zawartością tłuszczu, ale lekarz zaznaczył także, że nie działa ono tak dobrze na żoładek $^{12}$, jak kozie ${ }^{13}$. W końcu medyk stwierdził, że mleko ośle, krowie i końskie jest dobre dla przewodu pokarmowego, ale może także wywołać w nim zamieszanie ${ }^{14}$. Wypada skomentować ten fragment, konkludując, że wobec braku informacji o powszechności hodowli mlecznych koni ${ }^{15}$ i osłów ${ }^{16}$ autor De materia medica określił w tym passusie trójcę zwierząt hodowanych w celu otrzymania mleka. Kolejność ich wprowadzenia do tekstu (wpierw kozy, następnie owce, a na końcu krowy) także wydaje się nieprzypadkowa, gdyż odzwierciedla dane na ten temat utrwalone przez lekarza $z$ Anazarbos w Euporista vel de simplicibus medicinis oraz przez innych autorów antyku w ich dziełach ${ }^{17}$.

Wracając do kwestii paszy zwierząt dojnych, Dioskurides dodał, że każdy $z$ wymienionych rodzajów mleka doprowadza do zaburzeń przewodu pokarmowego i żołądka, gdy zwierzęta je produkujące żywią się powojem zwanym skammonia, ciemierzyca, szczyrem rocznym (Mercurialis annua L.) albo klematisem. Słyszał, że tak właśnie działo się w górach w kraju Westynów, którzy zamieszkiwali środkowo-wschodnią części Italii. Kozy pasąc się tam, spożywały

kazeiny odpowiedzialnych za reakcje uczuleniowe. Dzieła Dioskuridesa zdaja się wspierać hipotezę o rozpowszechnionych alergiach pokarmowych wywoływanych przez mleko, na które cierpiała znaczna część społeczeństwa. Por. Z. Rzeźnicka, M. Kokoszko, Dietetyka i sztuka kulinarna antyku i wczesnego Bizancjum

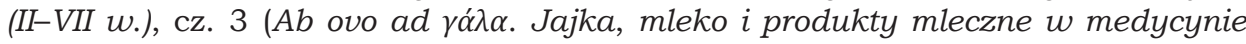
i sztuce kulinarnej [I-VII w.]), Łódź 2016, s. 87.

12 To znaczy, że ma stosunkowo silne działanie przeczyszczajace.

13 Dioskurides, De materia medica, II, 70, 1, 8-9.

14 Dioskurides, De materia medica, II, 70, 1, 10-11. Wszystkie zatem sa silnie przeczyszczające.

${ }^{15}$ Choć brakuje oceny dietetycznej mleka końskiego w De materia medica, jest ona jasno sformułowana w De alimentorum facultatibus Galena. Jest ono tam opisane jako wodniste i chude - Galeni de alimentorum facultatibus libri III, 681, 15 - 682, 1, [w:] Claudii Galeni opera omnia, ed. C.G. Kühn, vol. VI, Lipsiae 1823 [dalej: Galen, De alimentorum facultatibus]. Nie było ono zatem oceniane jako wartościowy pokarm.

${ }^{16} \mathrm{Na}$ temat tych zwierząt i produktów $\mathrm{z}$ nich otrzymywanych por. M. Ch ro nē, É panida stēn diatrofē kai stēn iatrikē sto Byzantio, Athenai 2012, s. 90-91, 362, 395.

${ }^{17} \mathrm{Na}$ temat wspomnianych trzech (kóz, owiec i krów) gatunków zwierząt gospodarskich, w tym uzyskiwanego $z$ ich udoju mleka, por. np. K.F. Kitchell, Animals in the ancient world from A to $Z$, London-New York 2014, s. 35-37, 76-77, 168-170. 
bowiem liście białej ciemierzycy (Veratrum album L.), a potem cierpiały $z$ powodu wymiotów. $Z$ kolei ich mleko miało silne właściwości przeczyszczające i wywoływało mdłości. Wypada nam dodać, że uwaga ta wskazuje na sposób wypasania zwierząt mlecznych, sugerując, że miały one wolny dostęp do roślinności (nawet tej, o której wiedziano, że ma silne właściwości farmakologiczne i w związku $z$ tym może być trująca), a zatem nie do końca udawało się kontrolować ich pokarm.

Gdy chodzi o obróbkę mleka, pozornie Dioskurides nie ma o tym wiele do powiedzenia w De materia medica. Po bliższym przyjrzeniu się jednak narracja skłania do szeregu wniosków $z$ dziedziny technologii kulinarnej znanej antykowi. Autor zaświadczył, że mleko poddawano działaniu wysokiej temperatury, a przegotowane $\mathrm{w}$ ten sposób uważane było za doprowadzające do zatwardzenia. Takie działanie miało zwłaszcza to, które zostało zagęszczone po zastosowaniu metody wrzucenia do niego rozgrzanych kamieni ${ }^{18}$. Ta ostatnia uwaga jest warta przemyślenia, a ponieważ narracja na ten sam temat została rozwinięta w tekście omawianym poniżej, uprawnia nas nadto do wnioskowania o względnej powszechności stosowania tejże metody, gdyż jej charakter czyni prawdopodobna konkluzję, że zapewne była wykorzystywana nie tylko przez lekarzy, lecz także inne osoby zajmujace się przygotowaniem mleka do spożycia.

Dioskurides pisał mianowicie, jak wspomnieliśmy, o podnoszeniu temperatury płynu przez wrzucanie do niego kamieni. Nie na darmo wybierano do tego celu otoczaki znajdowane w wodzie, któ-

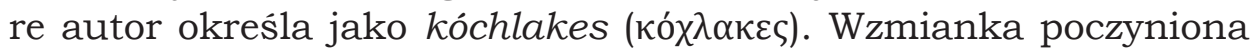
kilkadziesiąt lat później przez Galena, mówiąca o tym, że mogły być one zastępowane żelaznymi cylindrami ${ }^{19}$, wskazuje, iż wybierano płaskie kamienie o znacznej (i wygładzonej) powierzchni, która chłonęły i oddawały ciepło. Wrzucając do płynu kilka rozgrzanych kamieni, starano się zatem zwiększyć płaszczyznę oddawania ciepła i uczynić powierzchnię nagrzewania większą niż w przypadku postawienia naczynia $z$ mlekiem na żarze. W ten sposób temperatura wzrastała też bardziej równomiernie w całej objętości płynu, co ograniczało ryzyko jego przypalenia. Nadto, chociaż Dioskurides nadał procesowi gotowania mleka znaczenie procedury stosowa-

${ }_{18}$ Dioskurides, De materia medica, II, 70, 2, 7-8.

19 Galeni de simplicium medicamentorum temperamentis ac facultatibus libri XI, 267, 6-8, [w:] Claudii Galeni opera omnia, ed. C.G. Kühn, vol. XI-XII, Lipsiae 18261827 [dalej: Galen, De simplicium medicamentorum temperamentis ac facultatibus]. 
nej przez medyków w celu wygotowania obecnej w nim serwatki, domyślać się można, że przedstawiał nie tylko metodę uzyskania lekarstwa, lecz także sposób przedłużenia trwałości tego łatwo psującego się produktu. Notabene gotowanie mleka w powyższym celu na potrzeby domowe znamy także $z$ dzisiejszej praktyki.

Działanie terapeutyczne mleka wyliczone zostały przez Dioskuridesa $\mathrm{w}$ następujacy sposób. Mleko pomaga przy wewnętrznych owrzodzeniach i uszkodzeniach tkanek, zwłaszcza krtani, płuc, wnętrzności, nerek, pęcherza moczowego, przy swędzacych podrażnieniach na powierzchni ciała, wykwitach i zakłóceniach równowagi humoralnej. Świeże podaje się $z$ niegotowanym miodem, niewielka ilościa wody oraz odrobina soli. Mleko przegotowane staje się mniej wiatropędne. Dioskurides dodał, że jeżeli pacjent cierpi na owrzodzenia przewodu pokarmowego spowodowane przez napływ niepożądanych soków, pomoże mu mleko wygotowane do połowy pierwotnej objętości z użyciem rozgrzanych kamieni ${ }^{20}$. Lekarz pisał, że podawano je również dla załagodzenia skutków (wymienił bolesne nadżerki i poparzenia) działania trucizn takich jak kan-

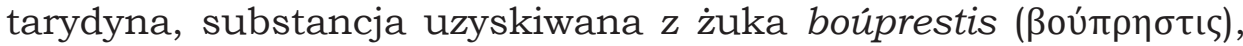
jad salamandry, trucizna otrzymywana z lulka czarnego, powoju Convolvulus oleifolius L., tojadu i zimowita jesiennego (Colchicum autumnale L. $)^{21}$. Do przeciwdziałania skutkom toksyn najlepiej było wykorzystać mleko krowie, które, wedle Dioskuridesa, także szczególnie nadawało się do stosowania jako płukanka, gdy pojawiały się owrzodzenia jamy ustnej i migdałków ${ }^{22}$. Z kolei mleko ośle zostało uznane przez autora De materia medica za najskuteczniejsze do płukania ust w przypadku problemów $z$ dziąsłami i chwiejnych $z_{\text {ębów }}^{23}$. Zmiany powstałe w przewodzie pokarmowym spowodowane przez napływ niepożądanych soków i bolesna niemożność oddania kału leczono mlekiem owczym, krowim lub kozim, przegotowanym z zastosowaniem metody wrzucania do niego goracych kamieni. Tak przygotowane, wprowadzane było w formie enemy, albo samo, albo zmieszane $z$ rzadka ptisáne $(\pi \tau \iota \sigma \alpha ́ v \eta)^{24}$ lub z wywarem z pszennej

${ }^{20}$ Dioskurides, De materia medica, II, 70, 2, 8 - 3, 5 .

${ }^{21}$ Dioskurides, De materia medica, II, 70, 5, 1-4.

${ }^{22}$ Dioskurides, De materia medica, II, 70, 5, 4-6.

${ }^{23}$ Dioskurides, De materia medica, II, 70, 5, 6-7.

${ }^{24}$ Rodzaj zupy (na bazie kaszy jęczmiennej) o zastosowaniu leczniczym. Por. E. D a r m s ta e d t e r, Ptisana: ein Beitrag zur Kenntnis der antiken Diaetetik, „Archeion" 1933, Bd. XV, s. 181-201; M. Grant, Roman Cookery. Ancient recipes for modern kitchens, London 2002, s. 70; A. Dalby, Food in the ancient world from 


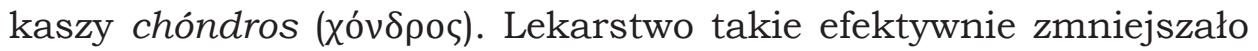
dolegliwości bólowe. Mleka używano też jako płukanki wewnętrznej leczacej owrzodzoną macicę 25 .

Mleko ludzkie ${ }^{26}$ było uważane za najsłodsze i najbardziej pożywne. Pomagało na bóle żołądka oraz leczyło suchoty, czyli fthisis

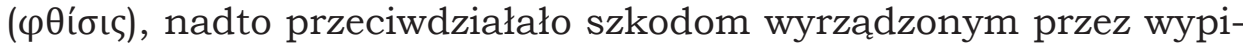
cie jednej $z$ trucizn, mianowicie substancji uzyskanej $z$ zajaca morskiego ${ }^{27}$. Dioskurides twierdził, że zmieszane $z$ rozdrobnionym kadzidłem wkraplane jest do oczu, by leczyć powstałe tam wskutek uderzenia wylewy. Stosuje się je także do smarowania miejsc zajętych przez podagre, a wtedy mieszane jest ze szczwołem plamistym

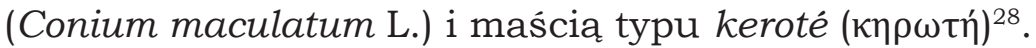

Lekarz z Anazarbos pisał również, że istniały przeciwwskazania medyczne w zastosowaniu mleka. Medyk utrzymywał, że jest ono nieodpowiednim pokarmem dla chorych na śledzionę, wątrobę, a także dla tych, którzy cierpią na dolegliwości tkanek twardych, majacych bóle i zawroty głowy, a także epileptyków. W tych przypadkach dopuszczalne jest jednak podawanie im mleka $z$ wydzielonym już skrzepem (schistón; $\sigma \chi\llcorner\sigma \tau o ́ v)$, a to w celu wywołania przeczyszczenia ${ }^{29}$.

Następnie Dioskurides przeszedł do poglądów zasłyszanych przez siebie, ale chyba takich, $z$ którymi się nie zgadzał. Pisał zatem

A to $Z$, London-New York 2003, s. 46; M. Kokoszko, Smaki Konstantynopola, [w:] Konstantynopol - Nowy Rzym. Miasto i ludzie w okresie wczesnobizantyńskim, red. M.J. Leszka, T. Wolińska, Warszawa 2011, s. 480; M. Ko ko s zko, K. J a gu -

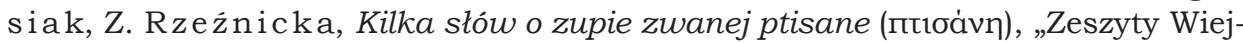

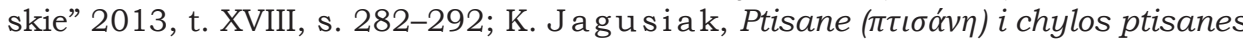

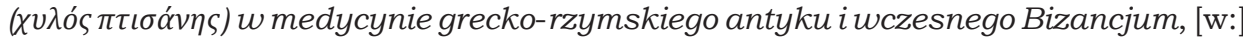
Historia panaceum. Między marzeniem a oszustwem, red. W. Korpalska, W. Ślusarczyk, Bydgoszcz 2016, s. 79-90.

${ }^{25}$ Dios kurides, De materia medica, II, 70, 5, 7-12.

${ }^{26} \mathrm{Na}$ temat zalet konsumpcji mleka ludzkiego, przede wszystkim w pierwszym okresie życia dziecka, pisało wielu starożytnych autorów, por. T. Parkin, The demography of infancy and early childhood in the ancient world, [w:] The Oxford handbook of childhood and education in the classical world, eds J. Evans Grubbs, T. Parkin, Oxford 2013, s. 50-57 [dalej: The Oxford handbook of childhood]. Por. też A. Pudsey, Children in Roman Egypt, [w:] The Oxford handbook of childhood, s. 486-490; J. Wilkins, Medical literature, diet, and health, [w:] A companion to food in the ancient world, eds J. Wilkins, R. Nadeau, Chichester 2015 [dalej: A companion to food], s. 63-65.

27 Rodzaj ślimaka należącego do rodzaju Alypsia L.

${ }^{28}$ Dioskurides, De materia medica, II, 70, 6, 1-5.

${ }^{29}$ Dioskurides, De materia medica, II, 70, 6, 6-9. 
o przekonaniu, że mleko od suki, która urodziła po raz pierwszy, doprowadza do wydelikacenia (lub usunięcia) włosów, gdy wsmaruje się je w owłosione miejsce, i działa też jako odtrutka, gdy się je wypije. W końcu mówiono także o nim, że powoduje wydalenie obumarlych płodów ${ }^{30}$.

Choć autor De materia medica nie włączył do swego dzieła jakiegoś obszerniejszego wyjaśnienia systematyki składników tworzacych mleko ${ }^{31}, z$ pozostawionej tam narracji jasno wynika, że nie było ono substancja jednorodną, a wszystkie jego części składowe zostały wymienione i opisane. Lekarz zaczął od serwatki, która, jak czytamy, po oddzieleniu od reszty nadaje się jako środek przydatny, gdy potrzeba łagodnego oczyszczania, tzn. kiedy wydalenie treści zalegających w układzie pokarmowym winno nastąpić bez środków farmakologicznych o radykalnym działaniu ${ }^{32}$. Pisał też, że takie nieinwazyjne procedury wymagane były w leczeniu melancholii, epilepsji, trądu, elefantiazy i wykwitów na całym ciele ${ }^{33}$. By otrzymać serwatkę, trzeba było doprowadzić do ścięcia mleka i Dioskurides tłumaczył, że mleko krzepnie, gdy jest gotowane w nowej ceramicznej chytrze, mieszane za pomoca świeżo ściętej gałąki figowej. Po jego zagotowaniu dodaje się do mleka nieco oksýmeli (ógú $\mu \varepsilon \lambda \iota)$, licząc

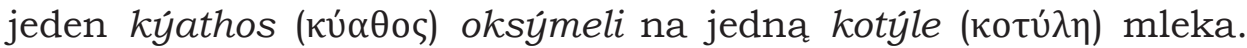
Dzięki tej metodzie serwatka łatwo oddziela się od skrzepu. Trzeba jednak było uważać, aby mleka nie przegotować, co osiagnać można było przez częste przecieranie brzegu naczynia gąbką nasaczona zimną woda i zanurzenie w nim srebrnego kubka wypełnionego zimną wodą. Serwatkę pijano ${ }^{34}$ co pewien czas w ilości jednej kotýle,

${ }^{30}$ Dioskurides, De materia medica, II, 70, 6, 9-12. Analogiczny, choć bardziej rozbudowany passus, znajduje się w De simlicium medicamentorum temperamentis ac facultatibus Galena - Galen, De simplicium medicamentorum temperamentis ac facultatibus, 269, 4-15, vol. XII. Galen jednoznacznie ocenia tego typu stwierdzenia jako nieprawdziwe. Rzeczony fragment wskazuje, że zarówno Dioskuridesa, jak i Galen korzystali (przynajmniej częściowo) $z$ tego samego źródła pisanego.

${ }^{31}$ Modelowa systematyka części składowych mleka obecna jest w twórczości Galena (De simplicium medicamentorum temperamentis ac facultatibus, 266, 2-3, vol. XII), a informacje tam zawarte wskazuja na to, że zarówno Dioskurides, jak i Galen dysponowali tą samą wiedzą ogólną i fachową.

${ }^{32}$ Niektóre spośród nich (jak np. ciemierzyca) zostały wymienione wcześniej w tej części narracji.

${ }_{33}$ Dioskurides, De materia medica, II, 70, 3, 6-10.

${ }^{34}$ Autor opisał w ten sposób dozowanie serwatki w celu wywołania przeczyszczenia. 
ale nie więcej niż pięć kotýle, spacerując w okresach między przyjęciem kolejnych porcji ${ }^{35}$.

Niniejszy fragment jest ciekawy nie tylko dla osób zajmujących się dziejami medycyny, lecz także dla historyka gastronomii, gdyż daje asumpt do dalszych przemyśleń na temat technologii kulinarnej charakterystycznej dla I w. n.e. Narracja Dioskuridesa daje bowiem dodatkowe wsparcie przedstawionym wnioskom, że mleko było produktem trudnym do gotowania przy ówczesnej technice kuchennej, i obrazuje kolejna metodę jego obróbki cieplnej, tym razem $\mathrm{w}$ naczyniach ceramicznych postawionych bezpośrednio na ogniu. Autor zaznaczył, że do opisanej procedury należało użyć nowego naczynia, co sugeruje, że garnki gliniane były słabo przystosowane do gotowania mleka, ponieważ resztki tego płynu były niemożliwe do usunięcia po zakończeniu rzeczonego procesu ze ścianek chytry. Można suponować, że czynnikiem do tego prowadzacym była szorstkość ich wewnętrznej powierzch$\mathrm{ni}^{36}$, zatem tendencja do przenikania płynu do porów powstałych w glinie, co skutkowało niemożnością wymycia stamtąd skarmelizowanego osadu. Jeżeli tak, to ściany wymienionego typu garnka nie były pokryte glazura, której warstwa zmniejszyłaby zagrożenie przywierania płynu i ułatwiała wyczyszczenie pojemnika ${ }^{37}$. Słowa lekarza wskazują też, że problem powstawania osadu starano się zmniejszyć, mieszając mleko oraz obniżając temperaturę ścianek naczynia za pomoca zimnej wody, co przeciwdziałało szybkiemu zwęgleniu przywierających resztek. Kontroli temperatury płynu sprzyjać też miało zanurzenie w mleku naczynia zawierającego wodę, co dodatkowo pozwalało uniknać wykipienia ${ }^{38}$. Dzięki wszystkim tym zabiegom można było doprowadzić do stosunkowo równomiernego ogrzewania całej objętości mleka, a w efekcie do prawie jednoczesnego ścięcia się białka w całej zawartości garnka. W końcu srebro, z którego zrobiony był wzmiankowany kubek, redukowało zagrożenie zepsucia tak otrzymanego produktu, gdyż

${ }^{35}$ Dioskurides, De materia medica, II, 70, 4, 1-10.

${ }^{36}$ Gładkość powierzchni była też zapewne drugim powodem, dla którego do gotowania mleka używano otoczaków.

${ }^{37} \mathrm{Na}$ temat budowy wewnętrznej powierzchni tego typu naczyń por. S. Birch, History of ancient pottery, vol. II, London 1858, s. 90-91; B.A. Au1t, Kitchens, [w:] A companion to food, s. 209.

38 Naczynie takie bowiem zmniejszało napięcie powierzchniowe, pozwalając swobodnie parować wodzie znajdujacej się w mleku. Zabieg ten ułatwiał zatem także proces zagęszczania mleka, gdyż przyspieszał odparowanie tej ostatniej. 
działało antybakteryjnie i grzybobójczo ${ }^{39}$. Wzmianka o gałące figowej, której sok był naturalna podpuszczką roślinną ${ }^{40}$, oraz o mieszaninie octu i miodu, $z$ których pierwszy przyczyniał się także do ścięcia białka obecnego w mleku ${ }^{41}$, sa $z$ kolei wskazaniem na kolejna metodę wykorzystywana w celu doprowadzenia do wydzielenia się skrzepu mlecznego. Zdradzaja nam zatem jeszcze jeden sekret technologii wykorzystywanej $\mathrm{w}$ serowarstwie antycznym. Uwagi autora na temat sera produkowanego $z$ mleka końskiego, które znajdziemy poniżej, sugeruja jednak, że lekarzowi znana była także podstawowa technologia wykorzystywana w tej ostatniej gałęzi rzemiosła spożywczego, tzn. metoda oparta na otrzymywaniu skrzepu dzięki dodaniu podpuszczki zwierzęcej, której rodzajom notabene medyk poświęcił cały fragment De materia medica ${ }^{42}$.

W Euporista vel de simplicibus medicinis brakuje rozbudowanej charakterystyki mleka. Występuje ono jednak w rozlicznych kuracjach, które wymienione sa przez autora, a dostępny materiał jest na tyle bogaty, że pozwala na cały szereg wniosków. Gdy chodzi o rodzaj kuracji, w których stosowano mleko, rozprawa wskazuje na następujące procedury. Mleko zalecane było do picia chorym na nerki ${ }^{43}$ i pęcherz moczowy ${ }^{44}$, podczas gdy potrawa $z$ gotowanej skrobi i kaszy typu chóndros, ale $z$ dodatkiem mleka, była rekomendowana jako składnik diety odpowiedniej dla chorych na dyzenterię i cierpiących na $\mathrm{kolki}^{45}$. Gotowanemu mleku koziemu przypisywano

39 Jony srebra działają dezaktywująco na enzym, którego bakterie, wirusy i grzyby używają w metabolizmie tlenowym, co powoduje ich obumieranie. Por. Q.L. F eng, J. Wu, G.Q. Chen, F.Z. Cui, T.N. Kim, J.O. Kim, A mechanistic study of the antibacterial effect of silver ions on Escherichia coli and Staphylococcus aureus, „Journal of Biomedical Materials Research" 2000, vol. LII, No. 4, s. 662-668; A.R. Shahver di, A. Fakhimi, H.Q. Shahverdi, S. Minaian, Synthesis and effect of silver nanoparticles on the antibacterial activity of different antibiotics against Staphylococcus aureus and Escherichia coli, „Nanomedicine: Nanotechnology, Biology and Medicine" 2007, vol. III, No. 2, s. 168-171. Stąd zastosowanie srebra w medycynie, $\mathrm{np}$. w leczeniu poparzeń. Por. H.J. Kla s en, Historical review of the use of silver in the treatment of burns. I. Early uses, „Burns” 2016, vol. XXVI, No. 2, s. 117-130.

40 Działanie to wzmiankuje w De materia medica - Di os ku rides, De materia medica, I, 128, 3, 6-7.

${ }^{41}$ Proces ten zwany jest denaturacją białka.

${ }^{42}$ Dioskurides, De materia medica, II, 75, 1, $1-3,8$.

${ }^{43}$ Dioskurides, Euporista vel de simplicibus medicinis, II, 107, 1, 1 - 3, 7 (potrawy z mlekiem - II, 107, 2, 1).

${ }_{44}$ Di os ku rides, Euporista vel de simplicibus medicinis, II, 111, 1, 1-6 (mleko słodkie - II, 111, 1, 6).

${ }^{45}$ Dioskurides, Euporista vel de simplicibus medicinis, II, 51, 1, $1-6,7$ (potrawy z mlekiem - II, 51, 2, 1-2). 
zdolność do leczenia tej pierwszej dolegliwości ${ }^{46}$. Świeże mleko ludzkie, krowie lub ośle miało pomagać na dolegliwości brzucha. Podobne właściwości przypisywano mleku zwierzęcemu gotowanemu za pomoca kamieni wrzuconych do garnka wypełnionego tym pły$n^{n}{ }^{47}$. Domyślać się wypada, że tak przetworzony produkt stosowano w rzeczonym przypadku jako środek łagodzacy i to w niewielkiej ilości. Inaczej, zwłaszcza drugie $z$ wymienionych, mogłoby wywołać niepożądaną reakcję organizmu charakteryzującego się deficytem laktazy. Picie świeżego mleka ludzkiego (jak należy rozumieć, przez ssanie piersi), koziego, owczego i krowiego pomagało zwalczyć chorobę określana jako fthísis ${ }^{48}$. Ssanie mleka $z$ piersi kobiecej miało też zmniejszyć częstotliwość krwotoków u pacjentów, którzy na nie cierpieli ${ }^{49}$. Choć spożycie mleka mogło powodować bóle głowy, plaster $z$ szafranu $z$ mlekiem (przyłożony na czoło) miał kłaść kres napływowi niepożądanych soków do tej części ciała ${ }^{50}$. Autor pisał też, że szakłak $z$ mlekiem stanowił okład na upławy $z$ narządów rodnych ${ }^{51}$. $Z$ kolei szafran zmieszany $z$ mlekiem do postaci kropli powinien był być środkiem przeciwbólowym ${ }^{52}$. To samo działanie miał mieć hematyt $z$ kobiecym mlekiem rozrobiony do identycznej konsysten$\mathrm{cji}^{53}$. Na chroniczne owrzodzenia i długotrwałe reumatyzmy pomagać miał sproszkowanych szafir i palona miedź połączona $z$ mlekiem zwierzęcym, sok $z$ dzikiej sałaty zmieszany $z$ kobiecym mlekiem

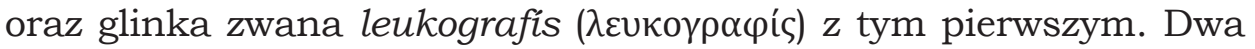
ostatnie specyfiki działały także skutecznie w przypadku oparzeńn ${ }^{54}$. Mleko kobiece $z$ kadzidłem, galasówki $z$ dębu skalnego ${ }^{55}$ (kókkos

${ }^{46}$ Dioskurides, Euporista vel de simplicibus medicinis, II, 50, 1, 1 - 3, 7 (mleko kozie - II, 50, 2, 3).

${ }^{47}$ Dioskurides, Euporista vel de simplicibus medicinis, II, 6, 1, 1-6 (mleko kobiece, krowie i ośle - II, 6, 1, 1-2).

${ }^{48}$ Dioskurides, Euporista vel de simplicibus medicinis, II, 40, 1, $1-2,8$ (mleko ludzkie, kozie, owcze i krowie - II, 40, 1, 4-5).

${ }^{49}$ Dioskurides, Euporista vel de simplicibus medicinis, II, 30, 1, $1-5,5$ (mleko kobiece - II, 30, 4, 7).

${ }^{50}$ Dios kurides, Euporista vel de simplicibus medicinis, I, 34, 1, 1-8 (mleko $-\mathrm{I}, 34,1,7)$.

${ }^{51}$ Dioskurides, Euporista vel de simplicibus medicinis, I, 88, 1, $1-2,6$ (mleko - II, 88, 2, 3).

${ }^{52}$ Dioskurides, Euporista vel de simplicibus medicinis, I, 35, 1, $1-2,7$ (mleko-I, 35, 2, 1).

${ }^{53}$ Dioskurides, Euporista vel de simplicibus medicinis, I, 35, 1, $1-2,7$ (mleko - I, 35, 2, 3).

${ }^{54}$ Dioskurides, Euporista vel de simplicibus medicinis, I, 36, 1, 1-8 (mleko - I, 36, 1, 3-4; I, 36, 1, 6).

${ }_{55}$ Quercus coccifera L. 


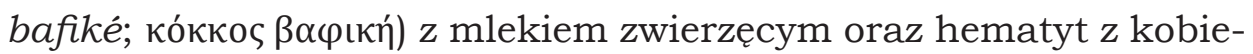
cym leczyły rozlegle wylewy, gdy środki te zostały wtarte w chore miejsca ${ }^{56}$. Pojawiajace się na źrenicach oczu białe plamki (zwane

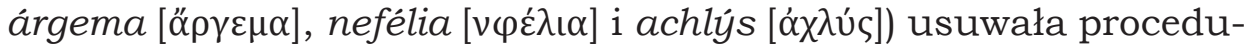
ra polegajaca na wsmarowaniu w oczy nasion rozmarynu rozrobionych $z$ mlekiem zwierzęcym. To samo lekarstwo miało też poprawiać ostrość widzenia ${ }^{57}$. $Z$ kolei na bóle i zapalenia uszu pomagało zakraplanie narządu słuchu za pomocą specyfiku składającego się $z$ soku $z$ oregano i mleka kobiecego. To samo działanie miał też sok makowy (opium) z mirra, olejkiem różanym, szafranem i mlekiem ludzkim ${ }^{58}$. Kiedy pojawiały się wysięki $z$ uszu, lekarz aplikował do tego narządu krople, w skład których wchodziła żółć wołowa zmieszana $z$ mlekiem ${ }^{59}$. Ten sam rodzaj medykamentu, tyle że przyrządzony $z$ tryskawca na mleku, był podawany do nosa w czasie kapieli osobom ciepiącym na żółtaczkę ${ }^{60}$. Mleko ośle miało służyć jako płukanka utwierdzająca zęby rozchwiane $z$ powodu paradontozy, a temu samemu środkowi przypisywano też zdolność redukowania stanu zapalnego dziąse ${ }^{61}$. $Z$ kolei picie mleka schistón miało ulżyć tym, którzy cierpieli na świąd ${ }^{62}$, a także tym, u których wykryto elefantiazę ${ }^{63}$. Poza tym maść $z$ soku makowego zmieszanego $z$ mlekiem ludzkim, szafranem oraz keroté $z$ dodatkiem olejku różanego leczyła podagrę i artretyzm ${ }^{64}$, gdy wypestkowane rodzynki $z$ mlekiem kobiecym były równie efektywne jako okład ${ }^{65}$, a pomagał

${ }^{56}$ Dioskurides, Euporista vel de simplicibus medicinis, I, 37, 1, 1-6 (mleko - I, 37, 1, 2-4).

57 Dioskurides, Euporista vel de simplicibus medicinis, I, 40, 1, $1-4,9$ (mleko - I, 40, 1, 4).

${ }^{58}$ Dioskurides, Euporista vel de simplicibus medicinis, I, 54, 1, $1-5,7$ (mleko - I, 54, 2, 2).

${ }^{59}$ Dioskurides, Euporista vel de simplicibus medicinis, I, 55, 1, 1-6 (mleko $-\mathrm{I}, 55,1,5)$.

${ }^{60}$ Di os kurides, Euporista vel de simplicibus medicinis, I, 59, 1, 1-9 (mleko - II, 59, 1, 3).

${ }^{61}$ Dioskurides, Euporista vel de simplicibus medicinis, I, 74, 1, 1 - 2, 9 (mleko - I, 74, 1, 3).

${ }^{62}$ Dioskurides, Euporista vel de simplicibus medicinis, I, 117, 1, 1-10 (mleko schistón - I, 117, 1, 9-10).

${ }^{63}$ Di os kurides, Euporista vel de simplicibus medicinis, I, 195, 1, 1-9 (mleko schistón-I, 195, 1, 4).

${ }^{64}$ Dioskurides, Euporista vel de simplicibus medicinis, I, 228, 1, $1-9,7$ (mleko ludzkie - I, 228, 4, 6-7).

${ }^{65}$ Dioskurides, Euporista vel de simplicibus medicinis, I, 228, 1, $1-9,7$ (mleko - I, 228, 6, 7-8). 
także szczwól plamisty ${ }^{66} \mathrm{z}$ mlekiem ludzkim ${ }^{67}$. Mleko zwierzęce wykorzystywane było nadto jako płukanka stosowana wewnętrznie, a łagodząca podrażnienia po zastosowaniu silnie działajacych, a tym samym podrażniających, lewatyw ${ }^{68}$. W końcu warto zaznaczyć, że w analizowanym dziele mleko występuje jako składnik rozlicznych odtrutek lub samodzielnie spełnia taka funkcję, co zostało wyłożone w księdze II Euporista vel de simplicibus medicinis. Przykładów jest bardzo wiele i wystarczy tu podać tylko kilka. Przy zatruciach akóniton (ákóvıtov), czyli tojadem południowym (Aconitum anthora L.), podawano opobálsamon (ó kiem zwierzęcym lub ludzkim ${ }^{69}$. Gdy $z$ kolei zagrożeniem dla zdro-

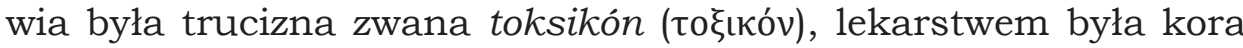
dębowa rozprowadzona $\mathrm{w}$ mleku krowim ${ }^{70}$. To ostatnie samodzielnie odgrywało rolę odtrutki, np. w zatruciach zimowitem jesiennym (efémeron; غ́

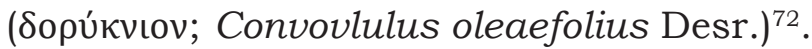

Podsumowując rozważania na temat mleka zawarte w twórczości Dioskuridesa, wypada zacząć od ogólnego i oczywistego stwierdzenia, że analiza przedstawionych danych prowadzi do wniosku na podstawie obu traktatów na tym samym zespole ustaleń. Gdy chodzi o terapeutyczne zastosowanie tego produktu, autor De materia medica i Euporista vel de simplicibus medicinis wyraził szczególna predylekcję dla zastosowań terapeutycznych mleka ludzkiego. Z kolei użycie terminu gála bez żadnego epitetu czy przydawki dopełniaczowej najprawdopodobniej stanowiło wskazówkę, że w danym przypadku wypadało zastosować mleko zwierzęce ${ }^{73}$. Treść obu traktatów stwarza przesłanki, by domniemywać, że autorowi

66 Conium maculatum L.

${ }^{67}$ Dioskurides, Euporista vel de simplicibus medicinis, I, 228, 1, 1 - 9, 7 (mleko ludzkie - I, 228, 8, 3-4).

${ }^{68}$ Dioskurides, Euporista vel de simplicibus medicinis, I, 55, 1, 1-5 (mleko - II, 55, 1, 2).

${ }^{69}$ Dioskurides, Euporista vel de simplicibus medicinis, II, 141, 1, 1 - 2, 8 (mleko zwierzęce - II, 141, 1, 2; mleko ludzkie - II, 141, 2, 6).

70 Dioskurides, Euporista vel de simplicibus medicinis, II, 143, 1, 1-8 (mleko krowie - II, 143, 1, 4).

${ }^{71}$ Dioskurides, Euporista vel de simplicibus medicinis, II, 152, 1, 1-9 (mleko krowie - II, 152, 1, 8).

${ }^{72}$ Dioskurides, Euporista vel de simplicibus medicinis, II, 153, 1, 1-4 (mleko - II, 152, 1, 1).

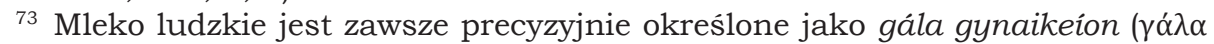

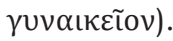


chodziło wtedy zwłaszcza o mleko kozie, owcze i krowie ${ }^{74}$. Zarówno jedno, jak i drugie dzieło potwierdzają też szczególną popularność pierwszych dwu rodzajów, sugerują zatem pierwszorzędne znaczenie hodowli kóz i owiec na obszarze śródziemnomorskim, gdy rola krów, jak trzeba się domyślać, była większa jedynie lokalnie, tzn. przede wszystkim na tych terenach, gdzie występował znaczny udział terenów nizinnych. Traktat Eporista vel de simplicibus medicinis nie daje też podstaw, by suponować, że mleko osłów zajmowało znacząca pozycję na liście rodzajów tego produktu dostępnych na rynku śródziemnomorskim, i nie wymienia w ogóle kobylego ${ }^{75}$, co także potwierdza przypuszczenia sformułowane na podstawie De materia medica.

Co do metod obróbki mleka i otrzymywania $z$ niego innych produktów, więcej danych przynosi nam De materia medica. $Z$ tekstu tego dzieła, jak też ze słów autora zawartych w Eporista vel de simplicibus medicinis, wynika, że w kuracjach wykorzystywano przede wszystkim mleko słodkie, co niekiedy jest zaznaczane w tekście przez dodanie do terminu gála epitetu glyký ( $\gamma \lambda$ vú). Notabene w niektórych poradach lekarz sugerował picie mleka bezpośrednio udojonego lub nawet wyssanie go $z$ piersi kobiecej. Informacje te wskazują na trudności $z$ utrzymaniem interesującego nas produktu w stanie najbardziej pożądanym przez medyków, zatem na fakt, że wszelkie jego rodzaje ulegały szybkiemu skwaśnieniu w ciepłym klimacie obszaru śródziemnomorskiego. Ponieważ zarówno w De materia medica, jak i w Eporista vel de simplicibus medicinis słodkie mleko zostało jasno wskazane przez autora jako pokarm mogacy doprowadzić do negatywnych skutków, np. do bóli głowy ${ }^{76}$, informacje te potwierdzałyby wcześniejsze uwagi na temat nietolerancji laktozy przez pacjentów Dioskuridesa. Oba traktaty sugerują zatem ograniczone spożycie tego pokarmu w postaci świeżej, a skutkiem tego większą popularność produktów przetworzonych, które powstawały na jego bazie ${ }^{77}$.

${ }^{74}$ Te trzy wymienione zostały w uwagach o kuracji suchot właśnie w takiej kolejności.

75 To ostatnie było wzmiankowane jedynie w De materia medica.

${ }^{6}$ Dioskurides, De materia medica, II, 70, 6, 7; Dioscuridis Peri haplon farmakon, I, 26, 1, 1 - 2, 7 (mleko słodkie - I, 26, 1, 4), [w:] Pedanii Dioscuridis Anazarbei De materia medica libri quinque, ed. M. Wellmann, vol. III, Berolini 1914 [dalej: Di os kurides, Euporista vel de simplicibus medicinis].

${ }^{77}$ Poza wymienionymi przez nas w dalszej części artykułu produktami mleko mogło mieć więcej zastosowań kulinarnych, choć należałoby je określić jako 
Zarówno w jednym, jak i w drugim traktacie brakuje dokładnych informacji, które mówiłyby o udziale mleka w diecie codziennej. Dane o uwzględnieniu w terapii chorych na dyzenterię i kolki zupy, która gotowano zaledwie $z$ dodatkiem tego produktu, sugeruje raczej, że dysponowano niewielkimi jego ilościami. Nie mogło zatem odgrywać roli rozpowszechnionego napoju ${ }^{78}$. Wnioski te potwierdzaja np. przedstawione informacje na temat dozowania serwatki zawarte w De materia medica. Podczas jednej kuracji pacjentowi podawano bowiem zwykle ok. ćwierć litra tego płynu, a maksymalna dawka nie mogła przekroczyć pięciokrotności wzmiankowanej ilości. $Z$ tekstu obu traktatów wypada też konkludować, że tylko niekiedy dysponowano większą ilością świeżego mleka na raz i dopiero wtedy można było przedłużyć jego trwałość do spożycia przez gotowanie albo dodanie takich konserwantów, jak miód lub sól. Długoletnie doświadczenie praktyczne mogło też wskazać, że zastosowanie podczas jego obróbki srebrnych naczyń miało także dobroczynny wpływ na jego trwałość.

Świeży produkt przetwarzano w celach medycznych na schistón, który to termin oznaczał mleko charakteryzujące się oddzieleniem skrzepu od serwatki. Informacje na temat tego produktu znajduja się zarówno w jednym, jak i drugim Dioskuridesowym traktacie. Choć fragmenty De materia medica sugeruja, że niekiedy wspomagano ten proces metoda podpuszczkowa, wydaje się, że schistón uzyskiwano głównie przez podgrzewanie mleka, gdyż wszelkie dodatki wzmiankowanego typu (czy to oparte na podpuszczce zwierzęcej, czy też roślinnej) zmieniały jego charakterystykę medyczną, co musiałoby zostać odnotowane.

W medycynie reprezentowanej przez Dioskuridesa rzadko jedynie pozostawiano mleko do naturalnego skiśnięcia $z$ zamiarem jego skonsumowania, o czym świadczy brak odnotowania przez niego terminu oksýgala (ółúy $\alpha \lambda \alpha$ ), który z kolei znamy $z$ dzieł innych autorów medycznych. Na przykład Galen poświęcił mu cały rozdział De alimentorum facultatibus. Nie ocenił go jednak wysoko jako pokarmu, wskazując na dolegliwości trawienne, jakie może ono

drugorzędne. Por. np. opis chleba wypiekanego z dodatkiem odrobiny białego płynu w Deipnosofistach Atenajosa $z$ Naukratis - Athenaei Naucratitae dipnosophistarum libri XV, III, 113 b-c $(79,14-23)$, rec. G. Kaibel, vol. I-III, Lipsiae-Berolini 1887-1890 [dalej: A tenajos z Naukratis, Deipnosofistae]; S. Mitche11, Food, culture, and environment in ancient Asia Minor, [w:] A companion to food, s. 286.

${ }^{78}$ Por. C. Chand e zo n, Animals, meat, and alimentary by-products, [w:] A companion to food, s. 136-137. 
wywołać w przypadku osób charakteryzujących się temperamentem umiarkowanym i zimnym ${ }^{79}$. $Z$ kolei Pliniusz, piszacy mniej więcej w tym samym czasie co lekarz z Anazarbos, utrzymywał, że jedynie barbarzyńcy pijali je regularnie. Zużywszy je w takiej postaci, nie mieli jednak do dyspozycji surowca, $z$ którego mogliby wyprodukować ser ${ }^{80}$. Powyższe fragmenty źródłowe skłaniają do konkluzji, że brak w diecie lub spożywanie naturalnie skwaśniałego mleka było jednym $z$ kryteriów odróżnienia ludów wysoko cywilizowanych od reszty ekumeny. Nadto miało wpływ na kształtowanie się tradycji rzemiosła spożywczego obu obszarów, której skutkiem było wyższe spożycie sera w świecie śródziemnomorskim.

\section{Serwatka}

$Z$ zachowanych danych należy rozumieć, że także serwatka była jednym $z$ regularnie przepisywanych fármaka ( $\varphi \alpha ́ \rho \mu \alpha \kappa \alpha)$. Fragment narracji Dioskuridesa, poświęcony jej w De materia medica, jest nierozerwalnie związany $z$ przedstawieniem natury mleka oraz metod jego przetwarzania i dlatego właśnie został wpleciony w nasze dywagacje na jego temat. $Z$ tekstu wynika, że stosowano ja regularnie jako łagodny środek oczyszczający organizm. Znaczenie tego specyfiku w praktyce medycznej I w. n.e. podkreśla znaczna szczegółowość opisu jej otrzymywania oraz dozowania. Dodać trzeba, że zarówno starszy od Dioskuridesa Celsus ${ }^{81}$, jak i młodszy od niego Galen $^{82}$ pisali o niej również, a podobieństwo ich poglądów także uprawdopodabnia prawidłowość wniosków wyciaganych na podstawie dorobku Dioskuridesa.

${ }^{79}$ Gale n, De alimentorum facultatibus, 689, 8 - 696, 6, vol. VI.

${ }^{0} \mathrm{Pliny}$, Natural history with an English translation in ten volumes, XI, 96, 239, transl. H. Rackham, W.H.S. Jones, D.E. Eicholz, vol. I-X, Cambridge, Mass., 1938-1963 [dalej: Pliniusz, Historia naturalis]. Warto zwrócić uwagę na to, że już u Homera picie mleka było jednym ze zwyczajów kulinarnych tradycyjnie kojarzonych $z$ niskim poziomem cywilizacyjnym, por. C. Chand e zon, op. cit., s. 143. Por. także S. Hitch, Anthropology and food studies, [w:] A companion to food, s. 120-121 i D. Braund, Food among Greeks of the Black Sea: the challenging diet of Olbia, [w:] A companion to food, s. 300-303, gdzie oboje autorzy zwracaja uwage na opis picia mleka u kojarzonych z dzikościa Scytów stworzony przez Herodota.

${ }^{81}$ A. Cornelii Celsi quae supersunt, II, 12, 1 a-c, ed. F. Marx, Lipsiae-Berolini 1915.

${ }^{82} \mathrm{G}$ ale n, De simplicium medicamentorum temperamentis ac facultatibus, 266, 7 - 269, 15, vol. XII. 
Z kolei w Eporista vel de simplicibus medicinis serwatka wymieniona jest tylko raz, jako środek pomocniczy w leczeniu elefantiazy $^{83}$. Ta rzadkość jej występowania w rzeczonym dziele nie tyle podważa prawdziwość danych obecnych w De materia medica, co raczej wskazuje na ograniczone spektrum zastosowań interesujacego nas produktu, zatem używania go przede wszystkim w procedurach oczyszczających. Notabene elefantiaza jest jedną $z$ opcji aplikacji wymieniona w De materia medica, co raz jeszcze wskazuje na spójność doktryn medycznej będącej podstawą obu traktatów.

\section{Ser}

Gdy chodzi o ser, to najważniejsze dane na jego temat w De materia medica zgrupowane zostały w charakterystyce zawartej w księdze II tego dzieła. Autor utrzymywał, że świeży ser niesolony ${ }^{84}$ jest pożywny, dobry dla żołądka, łatwy do przyswojenia, przyczynia się również do rozrostu tkanek i przeczyszcza umiarkowanie przewód pokarmowy. Poszczególne $z$ wymienionych działań charakteryzują go w różnym stopniu w zależności od tego, $z$ jakiego rodzaju mleka go wytworzono ${ }^{85}$. Lekarz pisał, że ser gotowany (tzn. ser uzyskany ze skrzepu poddanego działaniu wysokiej temperatury ${ }^{86}$ ), wyciśnięty, a potem upieczony staje się zatwardzajacy ${ }^{87}$. Użyty ${ }^{88}$ jako kataplazm leczy zapalenia oczu oraz ich zasinienia ${ }^{89}$. Świeży solony ser ${ }^{90}$ jest mniej pożywny, ale nadaje się do oczyszczania tkanek miękkich. Nadto oddziałuje negatywnie na żołądek, przewód pokarmowy i wnętrzności. Starszy ser tego typu staje się zatwardzający, a serwatka $z$ niego otrzymana bardzo dobrze odżywia

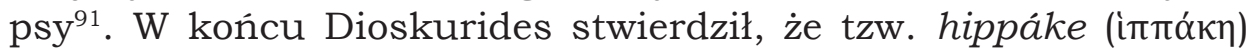

${ }^{83}$ Dioskurides, Eporista vel de simplicibus medicinis, I, 195, 1, 1-8 (serwatka - I, 195, 1, 7).

${ }^{84}$ Taki rodzaj nazywany jest przez autora nearós (vع $\alpha \rho$ só).

${ }^{85}$ Dioskurides, De materia medica, II, 71, 1, 1-4.

86 O skrzepłym serze pisał też Atenajos z Naukratis, cytując fragment Cyklopa Antyfanesa. Tradycja produkcji tego rodzaju sera byłaby zatem stara i sięgała przełomu V i IV w. p.n.e. Por. Atenajos z Naukratis, Deipnosophistae, IX, 402 e $(66,32)$.

87 Dioskurides, De materia medica, II, 71, 1, 4-5.

${ }^{88} \mathrm{Z}$ tekstu wynika, że chodzi o ser gotowany, odciśnięty i upieczony. Por. wnioski zamieszczone na końcu niniejszego tekstu.

89 Dioskurides, De materia medica, II, 71, 1, 5-6.

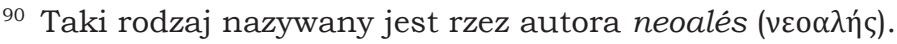

${ }^{91}$ Dioskurides, De materia medica, II, 71, 1, 6-9. 
to ser produkowany $z$ mleka kobylego. Ma on silny zapach i jest pożywny, podobnie jak produkt tego typu otrzymany $z$ mleka krowiego. Niektórzy $z$ kolei używają tego terminu do określenia podpuszczki otrzymanej z końskich żołądków ${ }^{92}$.

Przechodząc obecnie do podstawowych kuracji, w których stosowano ser, znajdujacych się w Eporista vel de simplicibus medicinis, należy stwierdzić, że Dioskurides częściej widział w nich zastosowanie stosunkowo niedawno wytworzonego produktu. Jako pokarm, czyli w ramach diety leczniczej, ser został polecony ciepiącym na kolki i dyzenterię. Do jedzenia serwowano wtedy delikatny i jeszcze niedojrzały, dobrze odciśnięty i rozdrobniony, a potem przesmażony na patelni wraz $z$ miodem ${ }^{93}$. Świeży i roztarty (lub być może kremowy) zostal wymieniony jako kataplazm leczacy zapalenia oczu $^{94}$. Okład $z$ analogicznej substancji miał kurować także podagrę i artretyzm ${ }^{95}$, a niedojrzałemu serowi, zmieszanemu $z$ jęczmienna kaszą typu álfita ( $\left.{ }^{\prime} \lambda \varphi \iota \tau \alpha\right)$ albo $z$ liśćmi selera i nałożonemu na klatkę piersiowa, przypisywano zdolność przeciwdziałania mimowolnym wymiotom ${ }^{96}$. Ser słony był zalecany przez Dioskuridesa wyłącznie zewnętrznie i nie stosowano go na delikatne tkanki. Po pierwsze, miał szybko usuwać zasinienia. Gdy jednak te nie ustępowały, należało okład wzmocnić przez dodanie soku z cebuli ${ }^{97}$. Po drugie, słony ser miał też pomagać ciepiącym $z$ powodu użądleń

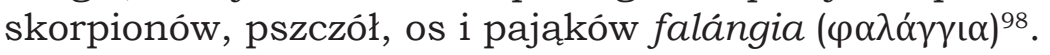

Dane na temat sera zaczerpnięte $z$ obu traktatów skłaniają również do wyciąnnięcia wniosków o spójności teorii medycznej odzwierciedlonej w obu dziełach. Ani w De materia medica, ani też w Euporista vel de simplicibus medicinis nie ma jednoznacznych informacji

92 Dioskurides, De materia medica, II, 71, 1, 10-12. Fragment o serze końskim jest kolejna ciekawostką, która podaje Dioskurides. Brakuje jednak danych, które potwierdzałyby istotne znaczenie tego typu produktu w schemacie spożycia ludności obszaru śródziemnomorskiego.

${ }^{93}$ Dioskurides, Eporista vel de simplicibus medicinis, II, 51, 1, $1-6,7$ (sposób przygotowania sera - I, 51, 6, 1-2; delikatny ser - I, 51, 6, 1).

${ }^{94}$ Dioskurides, Eporista vel de simplicibus medicinis, I, 30, 1, 1 - 2, 6 (świeży ser - I, 30, 2, 6).

${ }_{95}$ Dioskurides, Eporista vel de simplicibus medicinis, I, 228, 1, 1 - 9, 7 (świeży ser - I, 228, 6, 9).

${ }^{96}$ Dioskurides, Eporista vel de simplicibus medicinis, II, 8, 1, 1 - 6 (świeży ser - II, 8, 1, 4).

97 Dios kurides, Eporista vel de simplicibus medicinis, I, 53, 1, 1-3, 7 (działanie sera - I, 53, 3, 3-5; słony ser - I, 53, 3, 3).

98 Dioskurides, Eporista vel de simplicibus medicinis, II, 127, 1, $1-3,8$ (słony ser - II, 127, 3, 1). 
pozwalających na kwantyfikowanie spożycia sera. $Z$ drugiej strony warto zaznaczyć, że brak świadectw wskazujących na częste picie skwaśniałego mleka, $z$ wyraźnie zaznaczająca się w obu dziełach tendencją do ograniczania spożycia świeżego produktu tego typu i powszechności występowania zwierząt mlecznych, czyli znaczącej produkcji mleka, sugeruje rozpowszechnienie produkcji sera w celu zagospodarowania powstałych nadwyżek. Należy więc suponować, że Dioskurides i jego poprzednicy zainteresowali się tym produktem, ponieważ odgrywał znaczaca rolę w schemacie wyżywienia obszaru śródziemnomorskiego. Notabene zaliczenie przez lekarza $z$ Anazarbos sera do grupy substancji łatwo dostępnych, tzn. eupórista, jest kolejnym argumentem o pierwszorzędnym znaczeniu tego artykułu spożywczego w diecie I w. n.e.

Badacz kulinariów antycznych zwróci szczególną uwagę na to, że autor mówił przede wszystkim o dwu rodzajach tego produk-

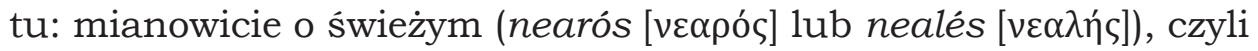
spożywanym przed okresem dojrzewania i dlatego produkowanym be $^{99}$ lub $z$ minimalna jedynie ilością konserwantów (neoalés

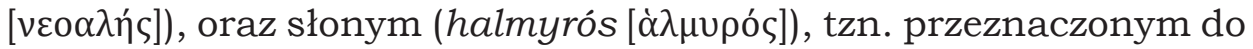
przechowywania, zatem zabezpieczanym za pomoca solanki, czyli

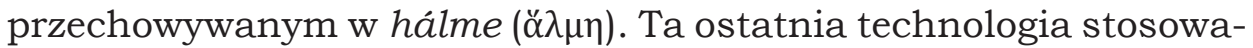
na jest powszechnie do dziś, chociażby w wytwarzaniu słynnej fety.

Co do cech fizycznych sera, dane zawarte w dorobku Dioskuridesa sa $z$ pozoru ubogie. Interpretujac informacje, można jednak pokusić się o hipotezę, że pierwszy $z$ wymienionych gatunków,

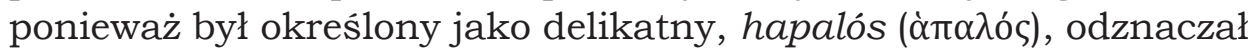
się mniej zbitą konsystencją od tej, która charakteryzowała produkty długo dojrzewajace. Lekarz opisał też raz ser tego typu za pomoca przymiotnika leíos ( $\left.\lambda \varepsilon \tilde{c}_{0} \varsigma\right)$, co sugeruje, że produkt ten był albo rozdrobniony, albo odznaczał się papkowata konsystencja, zatem należał do kategorii twarogów. Termin „[słony] ser dojrzały” (tyrós

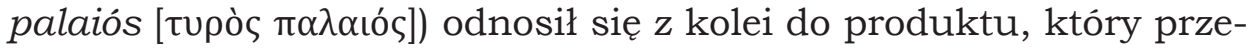
znaczony był do długiego przechowywania, zatem $z$ natury twardszego $^{100}$, a przynajmniej mocniej zbitego niż ser świeży. W teorii

${ }^{99}$ Przy użyciu sera do procedur oftalmologicznych nadawał się jedynie ser bez soli. Inaczej mógł on spowodować raczej podrażnienie niż wyleczenie chorych miejsc. Jednoznacznym zatem wnioskiem możliwym do wyciagnięcia na podstawie analizowanego materiału jest konkluzja, że nie wszystkie sery świeże produkowano $z$ dodatkiem soli.

100 Sól wyciagała $z$ sera wilgoć, która przedostawała się do roztworu, w którym się znajdował, a wskutek tego powodowała twardnienie tego produktu. 
lekarzy antyku i Bizancjum uważano je za zatwardzające, a cecha ta znajduje się także w opisie działania tego produktu w De materia medica. Dorobek Dioskuridesa sugeruje też, że gdy chodzi o technikę przetrzymywania serów stosowanych do celów medycznych, częściej używano te ich rodzaje, które przechowywano w słonej zalewie. Nie wysychały bowiem, zatem były łatwiejsze do przetworzenia np. w masę odpowiednią na kataplazm. Różnorodność surowca do produkcji sera i rozmaitość technologii sugeruje też znaczne zróżnicowanie gatunkowe sera, co potwierdzają dane zachowane w Historia naturalis Pliniusza ${ }^{101}$. Z drugiej strony jednak narracja Dioskuridesa skłania do przypuszczenia, że większość serów dostępnych na rynku nie dojrzewała w warunkach atmosferycznych, ale w płynie, i dlatego należała do kategorii białych.

Tylko dwa razy Dioskurides określił bliżej mleko, z którego zrobiono jeden ze znanych mu rodzajów sera. Po raz pierwszy uczynił tak przez referencję do jego nazwy, brzmiącej hippáke i wskazującej, że wytwarzano go $z$ mleka końskiego, gdy po raz drugi zaś przez porównanie rzeczonego gatunku do analogicznego produktu wytwarzanego $z$ mleka krowiego. Oba bowiem, jak zaznaczył, odznaczały się silnym zapachem. Ten pierwszy $z$ pewnością nie był typowy ani też często spotykany w obszarze śródziemnomorskim. Gdy chodzi o drugi, został on porównany z hippáke, gdyż zapewne również nie był rozpowszechniony na rynku w takim samym stopniu jak kozi i owczy. W innych przypadkach użycia terminu tyrós brakuje danych o rodzaju mleka, co nie tyle świadczyć może o tym, $\dot{z}$ e surowiec do jego produkcji był zupełnie obojętny, ale że lekarz uważał za oczywiste, iż najczęściej w terapii będzie miał do czynienia $z$ gatunkami wytwarzanymi $z$ koziego i owczego.

Dioskurides wzbogacił też naszą wiedzę o ważną wzmiankę dotyczaca wytwarzania sera $z$ użyciem goracej wody (lub serwatki). Technologia ta wydaje się analogiczna do metod wykorzystywanych dziś w otrzymywaniu mozzarelli czy sera halloumi. Ciekawe, że taki produkt także poddawano pieczeniu czy też smażeniu, co wskazywałoby, że tradycja grillowania tego drugiego ma już z pewnością ponad dwa tysiące lat.

101 Por. Pliniusz, Historia naturalis, XI, 97, 240 - 242. O rozmaitości gatunków sera w antyku i Bizancjum por. Z. Rzeźnicka, M. Kokoszko, Dietetyka $i$ sztuka kulinarna antyku $i$ wczesnego Bizancjum (II-VII w.), cz. 3, s. $148-161$. 


\section{Masło}

Omówienie kwestii dotyczacych masła stanowi w De materia medica kolejna część charakterystyki nabiału. Dioskurides utrzymywał, że wytwarza się je $z$ tłustego mleka owiec oraz kóz ${ }^{102}$. Autor opisał nadto, choć pobieżnie, technologię jego produkcji. Wedle tego świadectwa otrzymuje się je, potrząsając mlekiem przelanym do naczynia, które jest możliwe do zamknięcia tak długo, aż wydzieli się tłuszcz ${ }^{103}$. Gdy chodzi o cechy tego produktu i jego działanie terapeutyczne, to autor wyliczył je stosunkowo dokładnie. Masło zmiękcza i działa jak oliwa. Dlatego też doprowadza do przeczyszczenia przewodu pokarmowego, gdy zostaje wypite w znacznej ilości zamiast tej ostatniej. Zmieszane $z$ miodem i wtarte $w$ chore miejsce leczy bolesne problemy związane $z$ wyrzynaniem się zębów, jak i inne podrażnienia dziąseł małych dzieci, a także afty. Przyłożone na skórę odżywia i chroni ciało przed powstawaniem psydrákia $(\psi \nu \delta \rho \alpha ́ \kappa \iota \alpha)$, czyli pryszczy. Likwiduje też zapalenia i stwardnienia macicy, ale tylko te, które nie powoduja pojawienia się złego zapachu i nie trwają od dłuższego czasu. Masło wprowadza się do organizmu także w przypadkach dyzenterii i owrzodzeń jelita grubego, nadto miesza się ze środkami majacymi doprowadzić do (zebrania się, a następnie) usunięcia ropy $z$ organizmu, zwłaszcza gdy ta powstaje wskutek uszkodzeń tkanek twardych, błon otaczających narządy albo pęcherza moczowego. Powoduje ono także wypełnienie, oczyszczenie oraz zarośnięcie ran. Do tego pomaga pogryzionym przez żmiję. Dodaje się je też do niektórych dań zamiast oliwy, a do wypieków zamiast smalcu ${ }^{104}$. Od autora dowiadujemy się też, że $z$ masła otrzymywano leczniczą sadzę. Do nowej lampy wlewano masło, a zapaliwszy ja, przykrywano naczyniem ceramicznym, zwężającym się ku górze, które ma na dole otwory. Lampka paliła się, dopóki nie doszło do wyczerpania się pierwszej porcji tłuszczu, a potem następnej i kolejnej, w zależności od potrzeby. Zgromadzona sadzę zdejmowano ze ścianek naczynia za pomoca piórka. Uważano, że ma ona zdolność do wysuszania soków powodujących choroby oczu i jest nieco ściagajaca. Nadto przypisywano jej zdolność do stymulowania wypełniania się i zabliźniania ran ${ }^{105}$.

102 Z uwagą tą później polemizował Galen w De simplicium medicamentorm temperamentis ac facultatibus.

${ }^{103}$ Dioskurides, De materia medica, II, 72, 1, 1-4.

104 Dioskurides, De materia medica, II, 72, 1, 5-2, 8.

105 Dioskurides, De materia medica, II, 72, 3, 1-9. 
Z danych zawartych w Eporista vel de simplicibus medicinis jasno wynika, że masło było traktowane jako środek antyzapalny i przeciwbólowy. Stosowano je wtedy bez domieszek lub w połączeniu $z$ kozieradka lub hyzopem ${ }^{106}$. Samo albo zmieszane $z$ miodem uśmierzać miało ból związany $z$ wyrzynaniem się zębów ${ }^{107}$. Wymienione zostało także jako lek na dolegliwości określane jako zapalenia oczu. Nasączano nim wtedy wełnę i taki opatrunek nakładano na zajęte choroba miejsca ${ }^{108}$. Analogiczny kataplazm stosowano w przypadkach zapalenia przyusznic ${ }^{109}$, gdy $z$ kolei masło roztarte $z$ niepokalankiem i liśćmi winorośli wsmarowywano w jądra podlegle stanowi zapalnemu ${ }^{110}$, a zmieszane $z$ rozdrobnionymi liśćmi lulka czarnego dawało maść usuwająca narośle typu dothién $(\delta o \theta u \eta v v)^{111}$. Na pojawiajace się stwardnienia nazywane kondylómata

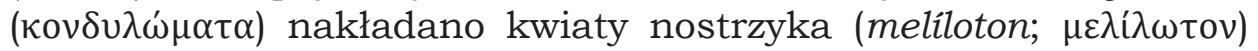

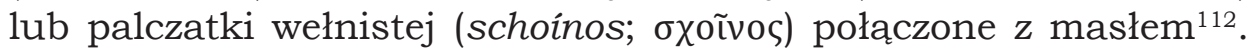
Okład $z$ tego tłuszczu (tym razem nałożonego na szarpie) przykładano też na uszkodzone tkanki miękkie i twarde ${ }^{113}$, a samym masłem smarowano powierzchniowe rany różnego typu, gdyż produkt ten uważano za substancję przyczyniająca się do ich zarastania ${ }^{114}$. Nadto rzeczona substancja miała też pomagać na kaszel. Łaczono wtedy masło na goraco $z$ odszumowanym miodem $\mathrm{w}$ równych ilościach i dodawano nieco kminu rzymskiego ${ }^{115}$. Podawano

106 Dioskurides, Eporista vel de simplicibus medicinis, II, 73, 1, $1-2,8$ (masło - II, 73, 2, 1-2; II, 73, 2, 5). Stosowano sok lub wywar z kozieradki, łaczacc je ze świeżym masłem (zapewne na ciepło), gdy hyzop gotowano w tym ostatnim.

${ }_{107}$ Dioskurides, Eporista vel de simplicibus medicinis, I, 71, 1, 1-6 (masło - I, 71, 1, 2).

108 Dioskurides, Eporista vel de simplicibus medicinis, I, 30, 1, 1 - 2, 6 (świeży ser - I, 30, 2, 3).

109 Dioskurides, Eporista vel de simplicibus medicinis, I, 139, 1, $1-2,7$ (masło-I, 139, 1, 1).

110 Dioskurides, Eporista vel de simplicibus medicinis, I, 132, 1, 1 - 2, 10 (masło-I, 132, 2, 9).

${ }^{111}$ Dioskurides, Eporista vel de simplicibus medicinis, I, 135, 1, 1 - 2, 7 (masło - I, 135, 2, 6-7).

112 Dioskurides, Eporista vel de simplicibus medicinis, I, 208, 1, 1 - 3, 5 (masło - I, 208, 2, 3; I, 208, 3, 3).

${ }^{113}$ Dioskurides, Eporista vel de simplicibus medicinis, I, 156, 1, 1-4 (masło-I, 156, 1, 2).

114 Dioskurides, Eporista vel de simplicibus medicinis, I, 178, 1, 1-3 (masło-I, 178, 1, 3).

115 Dioskurides, Eporista vel de simplicibus medicinis, II, 33, 1, 1-4 (masło - II, 33, 1, 1-2). 
je też doustnie pacjentom cierpiącym na suchoty ${ }^{116}$. Świeże masło używano jako enemę w dyzenterii ${ }^{117}$, a także uważano za środek (do zastosowania doodbytniczego) łagodzaccy podrażnienia po przepisaniu pacjentowi radykalnie działajacych lewatyw ${ }^{118}$. W końcu ciepłe masło było podawane (jako substytut oliwy) do picia jako środek mający doprowadzić do wymiotów, a w ten sposób usuwać $z$ organizmu substancje trujace ${ }^{119}$. Poza tym pokrywano nim też miejsce ugryzione przez żmiję ${ }^{120}$.

Wnioski $z$ analizy materiału dotyczącego masła sa następujące. Zarówno w De materia medica, jak i w Eporista vel de simplicibus medicinis znajdujemy informacje, które nie kłócą się ze sobą, a uzyskane na podstawie lektury obu traktatów dane powtarzaja się i uzupełniaja. Treść obu traktatów stanowczo zatem dowodzi istnienia ustalonych reguł użycia tego środka istniejących w medycynie czasów Dioskuridesa. Należy też zauważyć, że w obu przeanalizowanych dziełach masło pojawia się wielokrotnie jako samodzielne lekarstwo lub składnik leków złożonych. Teksty wyraźnie wskazują zatem, że przynajmniej świat medyczny był $z$ tym środkiem dobrze zaznajomiony. Mimo że oba traktaty nie dają możliwości dokładnej oceny roli masła w diecie, uwagi o jego stosowaniu jako substytutu oliwy sugeruja pierwszorzędna rolę tej ostatniej i to zarówno jako środka terapeutycznego, jak i artykułu spożywczego (co zgodne jest $z$ wiedzą ogólna na temat roli oliwy w świecie śródziemnomorskim). Dioskurides traktował bowiem masło przede wszystkim jako medykament, a dopiero potem jako tłuszcz spożywczy. Co ciekawe, sugerował też, że oliwa najczęściej wykorzystywana była do dań stanowiących dodatek do chleba, zatem do tzw. ópsa (ő $\psi \alpha)$, a smalec - w wypiekach. Dodajmy, że konkluzje o drugorzędnej jedynie roli masła jako pokarmu wspiera także wielce mówiacy w tym kontekście fakt, że Galen, choć omawiał je w swoim dziele De alimen-

116 Dioskurides, Eporista vel de simplicibus medicinis, II, 40, 1, $1-2,8$ (masło - II, 40, 2, 8).

117 Dioskurides, Eporista vel de simplicibus medicinis, II, 54, 1, $1-2,8$ (masło świeże - II, 54, 1, 2-3).

118 Dioskurides, Eporista vel de simplicibus medicinis, II, 55, 1, 1-5 (masło - II, 55, 1, 2).

119 Dioskurides, Eporista vel de simplicibus medicinis, II, 139, 1, $1-2,8$ (procedura - II, 139, 1, 1-3; ciepłe masło - II, 139, 1, 2).

120 Dioskurides, Eporista vel de simplicibus medicinis, II, 123, 1, $1-3,7$ (masło - II, 123, 3, 4). 
torum facultatibus ${ }^{121}$, tzn. w swym głównym traktacie dietetycznym, to jednak scharakteryzował je dokładnie dopiero w De simplicium medicamentorum temperamentis ac facultatibus, zatem w rozprawie poświęconej przede wszystkim lekarstwom ${ }^{122}$.

Uwaga $z$ De materia medica na temat produkowania masła $z$ mleka owczego i koziego, $z$ całkowitym pominięciem krowiego, wydaje się wspierać poczynione już uwagi na temat przewagi kóz i owiec w hodowli. Nie oznacza ona jednak, że interesujący nas produkt nie powstawał $\mathrm{z}$ mleka krów, ponieważ Galen, piszacy w ok. wiek po Dioskuridesie, zakwestionował ten fragment teorii lekarza $z$ Anazarbos, wskakujac na mleko krowie jako na podstawowy surowiec do wytwarzania tego tłuszczu ${ }^{123}$.

Chociaż informacje na temat technologii otrzymywania interesującego nas produktu są ograniczone, to jednak konkretne, a opisana przez autora De materia medica metoda jest stosowana aż do dzisiaj w celu otrzymania niewielkich ilości tego tłuszczu na potrzeby domowe. Euporsta vel de simplicibus medicinis dostarcza też sugestie co do sposobów jego przechowywania. Autor niekiedy zaznaczał, że pewne terapie wymagały użycia świeżego (prósfa-

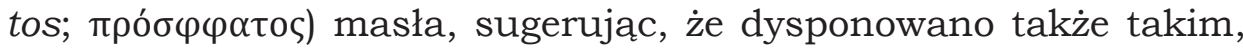
które było przechowywane przez dłuższy czas. Nie dał jednak żadnych wskazówek co do technik jego konserwacji. $Z$ drugiej strony wzmianki o poddawaniu tego produktu obróbce termicznej sugerują, że stosowano metodę klarowania, co dzięki usuwaniu $z$ niego frakcji podlegających szybkiej degradacji z pewnością zapewniało mu dłuższy okres trwałości. Notabene fragment De materia medica dotyczacy właściwości i metod przechowywania tłuszczów zwierzęcych potwierdza, że medycyna antyczna dysponowała odpowiednimi metodami przedłużania trwałości tego typu substancji ${ }^{124}$.

${ }^{121}$ Notabene jest ono przedstawione przede wszystkim jako pokarm (i kosmetyk) znany ludom zimniejszej strefy klimatycznej - Galen, De alimentorum facultatibus, 683, 12 - 684, 6, vol. VI.

${ }^{122}$ Galen, De simplicium medicamentorum temperamentis ac facultatibus, 272, 9 - 273, 18, vol. XII.

${ }^{123} \mathrm{G}$ ale n, De simplicium medcamentorum temperamentis ac facultatibus, 272, $12-15$, vol. XII.

${ }^{124}$ Dioskurides, De materia medica, II, 76, 1, 1 - 16, 8. Por. M. Kokoszko,

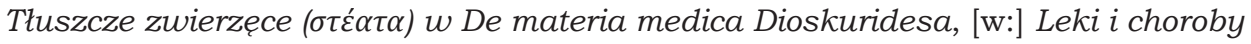
odzwierzęce, t. I, s. 19-31. 
Czas na wnioski podsumowujące zaprezentowane rozważania. Traktaty Dioskuridesa sa jednym $z$ najwcześniejszych przykładów rozbudowanej medycznej teorii mleka zachowanymi do naszych czasów. Poprzedzaja je jedynie uwagi zawarte w Hipokratejskim piśmie De diaeta $I-I V^{125}$ oraz (znacznie bardziej wyczerpujaca od nich pod względem informacji mówiących o zastosowaniu mleka w terapeutyce) zawartość De medicina Celsusa ${ }^{126}$. Warto jednak podkreślić, że niemal w tym samym czasie analogiczna teorię odnajdujemy $\mathrm{w}$ dziele $z$ pozoru dalekim od zainteresowań czysto medycznych - w Historia naturalis Pliniusza ${ }^{127}$. Potem pojawia się ona w dorobku takich medyków, jak Rufus z Efezu ${ }^{128}$, Galen ${ }^{129}$,

125 Por. mleko - Hippocratis de diaeta, 41, 4-7, eds R. Joly, S. Byl, Berlin 1984 [dalej: De diaeta I-IV]; serwatka - De diaeta I-IV, 42, 20-22; ser - De diaeta I-IV, 51, 1-4; element tłusty w mleku (podstawa do produkcji masła) - De diaeta I-IV, 51, 3.

${ }^{126}$ Nauki o mleku u Celsusa zostały już zanalizowane w następujacych stu-

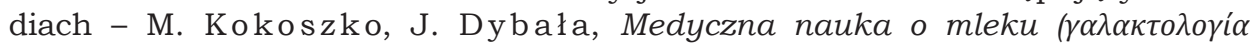

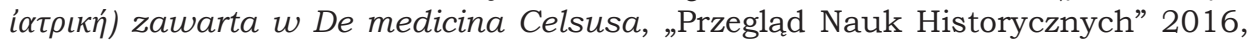
R. XV, nr 2, s. 5-43; eorundem, Milk in Medical Theory Extant in Celsus' De medicina, „Journal of Food Science and Engineering” 2016, vol. VI, No. 5, s. 267-279; eorundem, Medical science of milk included in Celsus' treatise De materia medica, „Studia Ceranea” 2016, vol. VI, s. 323-353; Z. Rzeźnicka, M. Kokoszko, Dietetyka i sztuka kulinarna antyku i wczesnego Bizancjum (II-VII w.), cz. 3, s. 64-84.

127 Encyklopedia tego autora przynosi wiele informacji o mleku i produktach mlecznych. Zawiera ona teorię analogiczną do tej zaprezentowanej przez Dioskuridesa. Por. Pliniusz, Historia naturalis, XI, 96, 236-239; XXVIII, 33, 123-130 (mleko); XXVIII, 36, 135 (oxygala); XI, 97, 240-242 (gatunki sera); XXVIII, 34, 131-132 (charakterystyka sera i zastosowania terapeutyczne); XXVIII, 35, 133134 (masło). Przykłady analogii terapii zanotowanych przez Pliniusza $z$ tym, które zachowali Celsus i Dioskurides, por. M. Kokos zko, J. Dybała, Medyczna nauka o mleku..., s. 29-34.

128 Jego prace nie zachowały się w całości, ale cytowane sa przez późniejszych asklepiadów. Por. mleko - Rufus d'Ephese, De renum et vesicae morbis, II, 19, 1 - 21, 7, [w:] Oeuvres de Rufus d'Ephese, eds C. Daremberg, C.E. Ruelle, Paris 1879 [dalej: ORE]; Rufus d'E phes e, De satyriasmo et gonorrhoea, 28, 5, [w:] ORE [dalej: Rufus z Efezu, De satyriasmo et gonorrhoea]; Oribasii collectionum medicarum reliquiae, II, 61, 1, 1 - 10, 2, eds I. Raeder, vol. I-IV, Lipsiae-Berolini 1928-1933 [dalej: Orybazjusz, Collectiones medicae]; Oribasii Synopsis ad Eustathium filium, I, 40, 1, 1 - 6, 3, [w:] Oribasii synopsis ad Eustathium filium et libri ad Eunapium, eds I. Raeder, vol. VI, 3, Leipzig 1964 [dalej: Orybazjusz, Synopsis ad Eustathium filium]; Aetii Amideni libri medicinales I-VIII, II, 86, 1 - 87, 15, eds A. Olivieri, Lipsiae-Berolini 1935-1950 [dalej: Aecjusz z Amidy, Iatricorum libri]; ser-Rufus z Efezu, De satyriasmo et gonorrhoea, 28, 5.

129 Mleko i produkty mleczne zostały scharakteryzowane w wielu utworach Pergamończyka. Najbardziej obszerne opisy właściwości dietetycznych i farmakologicznych tych produktów por. Galen, De alimentorum facultatibus, 681, 
Orybazjusz ${ }^{130}$, Aecjusz z Amidy ${ }^{131}$, Paweł z Eginy ${ }^{132}$ oraz w późniejszej literaturze medycznej. Oznacza to, że temat ten uznano za ważny $z$ punktu widzenia lecznictwa, a przez to interesujący zarówno lekarzy, jak i szerszą i ciekawa świata publiczność, dla której pisał Pliniusz. Co do samej teorii, była ona wystarczająco rozbudowana, by uznać ja za oddzielna gałąz $\mathrm{w}$ ramach dietetyki i farmakologii.

Przytoczone dane wskazuja, że nauka ta w kształcie utrwalonym w De materia medica oraz w Euporista vel de simplicibus medicinis uformowała się przed I w. n.e. Podobieństwa występujące między dorobkiem $z$ jednej strony Dioskuridesa a $z$ drugiej Celsusa i Pliniusza sugerują, że wszyscy oni korzystali $z$ gotowych już i powszechnie przyjętych wzorców. Bezsprzecznie tworzyli je lekarze greccy (dokładniej: greckojęzyczni).

Zachowany materiał dowodzi, że nauka o mleku nie została zmodyfikowana po I w. n.e. Żadnych znaczących zmian do zakresu jej teorii nie wniósł nawet w II w. Galen. Fakt ten świadczy o braku rozwoju medycyny w tym zakresie i czerpaniu $z$ dorobku utrwalonych autorytetów również i w epoce Bizancjum. Powód tego zjawiska wymaga dalszych badań, ale wypada zasugerować, że wobec, $z$ jednej strony, istnienia skończonej formy teorii już przed I w., a $z$ drugiej, wskutek braku nowych czynników modyfikujacych

11 - 699, 9 (mleko, serwatka - 681, 11 - 689, 7; ser - 696, 7 - 699, 9; masło - 683, 11 - 684, 6; G ale n, De simplicium medicamentorum temperamentis ac facultatibus libri XI, 263, 12 - 269, 15, vol. XII, (mleko - 263, 12 - 269, 15, vol. XII; serwatka - 266, 7 - 269, 15, vol. XII; ser - 269, 16 - 272, 8, vol. XII; masło - 272, 9 - 273, 18, vol. XII).

130 Informacje na jego temat znajdujemy zarówno w Collectiones medicae, jak i w Synopsis ad Eustathium filium oraz w Libri ad Eunapium. Najobszerniejsze sa w pierwszym $z$ wymienionych dzieł. Por. Orybazjusz, Collectiones medicae, II, 59, 1, 1 - 14, 5 (mleko - II, 59, 1, 1-11, 1; XV, 2, 1, 1 - 3, 1; serwatka - II, 59, 3, 2; $\mathrm{XV}, 2,3,1-5,1$; ser - II, 59, 11, 1 - 14, 5; XV, 2, 5, 1; masło - XI, $\beta, 14,1-9$; XV, $2,8,1-5)$. Należy nadto pamiętać, że oprócz charakterystyk opisowych wszystkie $z$ wymienionych produktów znalazły się w księdze III Collectiones medicae, gdzie zamieszczone sa listy substancji wedle ich dominujaccej cechy dietetycznej.

${ }^{131}$ Mleko - A e cjusz z A midy, Iatricorum libri, II, 86, 1 - 95, 28; II, 97, 1-11; serwatka - II, 95, 28-58; ser - II, 101, 1 - 103, 7; masło - II, 104, 1-13. W Iatricorum libri odnajdujemy także kategorie dietetyczne i farmakologiczne, które zostały włączone do księgi III Collectiones medicae. Znajduja się w księdze II encyklopedii medycznej skomponowanej przez Aecjusza z Amidy.

132 Por. ogólna charakterystyka mleka - Paulus Aegineta, VII, 3, 3, 2-11, ed. I.L. Heiberg, vol. I-II, Lipsiae-Berolini 1921-1924; serwatka - VII, 3, 3, 2-5; ser - VII, 3, 19, 95-101; masło - VII, 3, 2, 63-66. 
wynikającego $z$ niezmienności gamy dostępnych medykom środków terapeutycznych, nie istniała potrzeba przebudowy założeń owej gałęzi medycyny. Jest zatem prawdopodobne, że zarówno Dioskurides, jak i potem Orybazjusz, Aecjusz z Amidy czy Paweł $z$ Eginy spisywali klasyczne już wtedy doktryny, gdyż także w ich czasach zmiany w wyborze dostępnych produktów spożywczych (w tym mlecznych) i w metodach ich wytwarzania (więc także w charakterystyce używanych środków leczniczych) były powolne lub w ogóle nie występowały.

Jeżeli tak było, to zarówno traktaty Dioskuridesa, jak i inne teksty medyczne zawierające naukę o mleku staja się źródłami nie tylko do historii medycyny sensu stricto, lecz także ważnymi przekazami informującymi o gospodarce antycznej i wczesnobizantyńskiej, zwłaszcza o tej jej gałęzi, jaką była hodowla zwierząt mlecznych. Poza tym, traktujacc o technologii wytwarzania poszczególnych substancji, ukazują one w rzeczywistości popularne metody wykorzystywane w kuchni owego okresu. Nadto rzucaja światło na schemat spożycia poszczególnych artykułów żywnościowych, mówiąc w ten sposób także o społeczeństwie owego. W końcu warto zauważyć, że w charakterystykach mleka i jego pochodnych zawartych w traktatach Diokuridesa (podobnie jak w dziełach Celsusa i Pliniusza, a potem w późniejszej literaturze medycznej) z rzadka jedynie odnajdujemy wzmianki na temat związków między leczeniem intersującymi nas substancjami a luksusowymi (ponieważ egzotycznymi) produktami sprowadzanymi spoza obszaru śródziemnomorskiego. Czyni to jeszcze bardziej prawdopodobnym wyrażone już przypuszczenie, że informacje tam zawarte odzwierciedlają schemat spożycia typowy dla niższych i średnich warstw społecznych. Skutkiem tego dzieło lekarza $z$ Anazarbos stają się znakomitym materiałem referencyjnym do wykorzystania zwłaszcza w badaniach nad życiem codziennym szerokich warstw społecznych, winny zatem na stałe zainteresować nie tylko historyka medycyny.

\section{Bibliografia}

\section{$\dot{Z}_{\text {RÓDEA DRUKOWANE }}$}

Aetii Amideni libri medicinales I-VIII, eds A. Olivieri, Lipsiae-Berolini 1935-1950. Athenaei Naucratitae dipnosophistarum libri XV, rec. G. Kaibel, vol. I-III, LipsiaeBerolini 1887-1890. 
A. Cornelii Celsi quae supersunt, ed. F. Marx, Lipsiae-Berolini 1915.

Dioscuridis Peri haplon farmakon, [w:] Pedanii Dioscuridis Anazarbei De materia medica libri quinque, ed. M. Wellmann, vol. III, Berolini 1914.

Galeni de alimentorum facultatibus libri III, [w:] Claudii Galeni opera omnia, ed. C.G. Kühn, vol. VI, Lipsiae 1823.

Galeni de simplicium medicamentorum temperamentis ac facultatibus libri XI, [w:] Claudii Galeni opera omnia, ed. C.G. Kühn, vol. XI-XII, Lipsiae 1826-1827.

Hippocratis de diaeta, eds R. Joly, S. Byl, Berlin 1984.

Oribasii collectionum medicarum reliquiae, eds I. Raeder, vol. I-IV, Lipsiae-Berolini 1928-1933.

Oribasii Synopsis ad Eustathium filium, [w:] Oribasii synopsis ad Eustathium filium et libri ad Eunapium, eds I. Raeder, vol. VI, 3, Leipzig 1964.

Paulus Aegineta, ed. I.L. Heiberg, vol. I-II, Lipsiae-Berolini 1921-1924.

Pedanii Dioscuridis Anazarbei De materia medica libri V, ed. M. Wellmann, vol. I-III, Berolini 1906-1914.

Pliny, Natural history with an English translation in ten volumes, transl. H. Rackham, W.H.S. Jones, D.E. Eicholz, vol. I-X, Cambridge, Mass., 1938-1963.

Rufus d'Ephese, De renum et vesicae morbis, [w:] Oeuvres de Rufus d'Ephese, eds C. Daremberg, C.E. Ruelle, Paris 1879.

Rufus d'Ephese, De satyriasmo et gonorrhoea, [w:] Oeuvres de Rufus d'Ephese, eds C. Daremberg, C.E. Ruelle, Paris 1879.

\section{Opracowania}

Ault B.A., Kitchens, [w:] A companion to food in the ancient world, eds J. Wilkins, R. Nadeau, Chichester 2015, s. 206-211.

Birch S., History of ancient pottery, vol. II, London 1858.

Braund D., Food among Greeks of the Black Sea: the challenging diet of Olbia, [w:] A companion to food in the ancient world, eds J. Wilkins, R. Nadeau, Chichester 2015, s. 296-308.

Chandezon C., Animals, meat, and alimentary by-products, [w:] A companion to food in the ancient world, eds J. Wilkins, R. Nadeau, Chichester 2015, s. $135-146$.

Chronē M., É panida stēn diatrofē kai stēn iatrikē sto Byzantio, Athenai 2012.

Dalby A., Food in the ancient world from A to Z, London-New York 2003.

Darmstaedter E., Ptisana: ein Beitrag zur Kenntnis der antiken Diaetetik, „Archeion” 1933, Bd. XV, s. 181-201.

Dietetyka i sztuka kulinarna antyku i wczesnego Bizancjum (II-VII w.), cz. 2 (Pokarm dla ciała i ducha), red. M. Kokoszko, Łódź, 2014.

Feng Q.L., Wu J., Chen G.Q., Cui F.Z., Kim T.N., Kim J.O., A mechanistic study of the antibacterial effect of silver ions on Escherichia coli and Staphylococcus aureus, „Journal of Biomedical Materials Research” 2000, vol. LII, No. 4, s. 662-668. 
Gabriel R.A., Man and wound in the ancient world. A history of military medicine from Sumer to the fall of Constantinople, Washington 2012.

Grant M., Roman Cookery. Ancient recipes for modern kitchens, London 2002.

Hitch S., Anthropology and food studies, [w:] A companion to food in the ancient world, eds J. Wilkins, R. Nadeau, Chichester 2015, s. 116-122.

Howe T., Domestication and breeding of livestock. Horses, mules, asses, cattle, sheep, goats, and swine, [w:] The Oxford handbook of animals in classical thought and life, ed. G.L. Campbell, Oxford 2014, s. 99-108.

Howe T., Value economics. Animals, wealth, and the market, [w:] The Oxford handbook of animals in classical thought and life, ed. G.L. Campbell, Oxford 2014, s. $136-155$.

Jagusiak K., Ptisane ( $\pi \tau \iota \sigma \alpha ́ v \eta) ~ i ~ c h y l o s ~ p t i s a n e s ~(\chi v \lambda o ́ s ~ \pi \tau \iota \sigma \alpha ́ v \eta \varsigma) ~ w ~ m e d y c y n i e ~ g r e c-$ ko-rzymskiego antyku i wczesnego Bizancjum, [w:] Historia panaceum. Między marzeniem a oszustwem, red. W. Korpalska, W. Ślusarczyk, Bydgoszcz 2016, s. 79-90.

Kitchell K.F., Animals in the ancient world from A to Z, London-New York 2014.

Klasen H.J., Historical review of the use of silver in the treatment of burns. I. Early uses, „Burns” 2016, vol. XXVI, No. 2, s. 117-130.

Kokoszko M., Ryby i ich znaczenie $w$ życiu codziennym ludzi późnego antyku i Bizancjum (IV-VII w.), Łódź 2005.

Kokoszko M., Smaki Konstantynopola, [w:] Konstantynopol- Nowy Rzym. Miasto i ludzie $w$ okresie wczesnobizantyńskim, red. M.J. Leszka, T. Wolińska, Warszawa 2011, s. 471-575.

Kokoszko M., The Common Oat as Food and Medicament in Greek Medical Treatises of Antiquity and Byzantium, II-VII c. AD, [w:] Tasting Cultures: Thoughts for Food, ed. M.J. Pires, Oxford 2015, s. 99-113.

Kokoszko M., Rzodkiew (Raphanus L.) w wybranych źródłach antyku i Bizancjum, [w:] Lek roślinny 4. Produkty pochodzenia roślinnego w lecznictwie, dietetyce, kosmetyce, ekonomice i kulturze popularnej, red. B. Płonka-Syroka, A. Syroka, Wrocław 2015, s. 15-33.

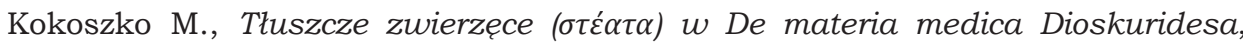
[w:] Leki i choroby odzwierzęce, t. I, red. L. Wdowiak, B. Płonka-Syroka, A. Syroka, Wrocław 2016, s. 19-31.

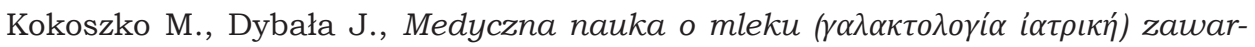
ta $w$ De medicina Celsusa, „Przegląd Nauk Historycznych” 2016, R. XV, nr 2, s. $5-43$.

Kokoszko M., Dybała J., Milk in Medical Theory Extant in Celsus' De medicina, „Journal of Food Science and Engineering” 2016, vol. VI, No. 5, s. 267-279.

Kokoszko M., Jagusiak K., Rzeźnicka Z., Kilka słów o zupie zwanej ptisane

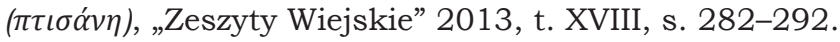

Kokoszko M., Jagusiak K., Rzeźnicka Z., Cereals of antiquity and early Byzantine times. Wheat and barley in medical sources (second to seventh centuries AD), Łódź 2014. 
Kokoszko M., Jagusiak K., Rzeźnicka Z., Dietetyka $i$ sztuka kulinarna antyku i wczesnego Bizancjum (II-VII w.), cz. 1 (Zboża i produkty zbożowe $w$ źródłach medycznych antyku i wczesnego Bizancjum), Łódź 2014.

Kokoszko M., Jagusiak K., Rzeźnicka Z., Rice as food and medication in ancient and Byzantine medical literature, „Byzantinische Zeitschrift” 2015, Bd. CVIII, Nr. 1, s. 129-155.

Mitchell S., Food, culture, and environment in ancient Asia Minor, [w:] A companion to food in the ancient world, eds J. Wilkins, R. Nadeau, Chichester 2015, s. 285-295.

Nutton V., Ancient medicine, London-New York 2005.

Parkin T., The demography of infancy and early childhood in the ancient world, [w:] The Oxford handbook of childhood and education in the classical world, eds J. Evans Grubbs, T. Parkin, Oxford 2013, s. 40-61.

Pudsey A., Children in Roman Egypt, [w:] The Oxford handbook of childhood and education in the classical world, eds J. Evans Grubbs, T. Parkin, Oxford 2013, s. 484-509.

Riddle J.M., Dioscurides on pharmacy and medicine, Austin 1985.

Rzeźnicka Z., Kokoszko M., Czosnek $w$ medycynie wczesnego Bizancjum na przykładzie pism Orybazjusza, [w:] Lek roślinny 4. Produkty pochodzenia roślinnego $w$ lecznictwie, dietetyce, kosmetyce, ekonomice i kulturze popularnej, red. B. Płonka-Syroka, A. Syroka, Wrocław 2015, s. 49-61.

Rzeźnicka Z., Kokoszko M., Odchody zwierzęce w terapeutyce późnego antyku $i$ wczesnego Bizancjum na przykładzie pism Galena i Aecjusza z Amidy, [w:] Leki i choroby odzwierzęce, t. I, red. L. Wdowiak, B. Płonka-Syroka, A. Syroka, Wrocław 2016, s. 33-46.

Rzeźnicka Z., Kokoszko M., Dietetyka i sztuka kulinarna antyku i wczesnego Bizan-

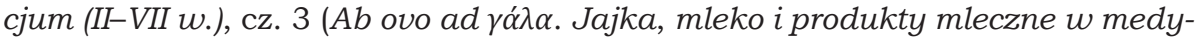
cynie $i$ sztuce kulinarnej [I-VII w.I), Łódź 2016.

Scarborough J., Roman medicine and the legions. A reconsideration, „Medical History" 1968, t. XII, No. 3, s. 254-261.

Shahverdi A.R., Fakhimi A., Shahverdi H.Q., Minaian S., Synthesis and effect of silver nanoparticles on the antibacterial activity of different antibiotics against Staphylococcus aureus and Escherichia coli, „Nanomedicine: Nanotechnology, Biology and Medicine” 2007, vol. III, No. 2, s. 168-171.

Stamatu M., Dioskurides, [w:] Antike medizin. Ein Lexikon, hrsg. K.-H. Leven, München 2005, kol. 227-229.

Wilkins J., Medical literature, diet, and health, [w:] A companion to food in the ancient world, eds J. Wilkins, R. Nadeau, Chichester 2015, s. 59-66. 
Maciej Kokoszko, Krzysztof Jagusiak, Jolanta Dybąa

\section{The doctrine of Dioscurides with regard to milk: a source study}

Dedanius Dioscurides of Anazarbos, a physician working for the Roman army living in the first century $\mathrm{AD}$, secured his place in history of medicine as the author of two works, namely De materia medica, and Euporista vel de simplicibus medicinis. Among the substances referred to by the doctor of Anazarbos we find numerous animal-based products, including milk (gála; үó $\lambda \alpha$ ), whey (órros;

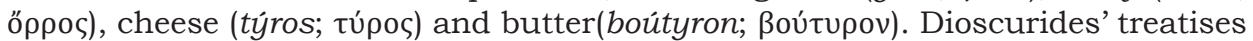
belong to the group of the oldest surviving examples of highly developed medical theory of milk. The subject in question was considered to be important as regards therapy, and therefore interesting to both doctors and the wider public keen on acquiring knowledge (such was the intended readership of Pliny). As for the theory, it was sufficiently developed to be seen as a separate branch of dietetics and pharmacology.

The data discussed in the present study indicate that this medical doctrine had developed before the first century $\mathrm{AD}$, prior to being formulated in the form observable in De materia medica and in Euporista vel de simplicibus medicinis. The similarities between the accounts of Dioscurides on the one hand and Celsus and Pliny on the other suggest that all these doctors made use of established and widely adopted standards.

The surviving evidence confirms that the doctrine on milk was not modified after the first century AD. Galen, writing in the second century, did not introduce any major changes with regard to its theory. Dioscurides's treatises and other medical texts which contained discussions on the doctrine concerning milk can not only be useful as sources for history of medicine sensu stricto, but also for the study of ancient and early Byzantine economy, particularly as regards the breeding of milk animals. In addition to that, by discussing the technology of production of individual substances, the texts in question illustrate the popular methods used in contemporary cuisine. Moreover, they shed light on the patterns of consumption of various foodstuffs, and in consequence impart information on the contemporary society. Thus, the works of the doctor of Anazarbos can rightly seem to provide excellent reference material, in particular for the study of the daily life of most social classes, and as such they should be seen as a vital historical source, useful not only for historians of medicine.

Keywords: Dioscorides, ancient medicine, Byzantine medicine, ancient food processing technology. 